\title{
RELIABILITY OF CONDITIONED ORIENTATION REFLEX AUDIOMETRY
}

By

\author{
Mitsuko KIMURA
}

\author{
From tne Department of Otolaryngology, Niigata University
} School of Medicin (Director: Professor H. Ino)

Conditioned orientation reflex audiometry was reported by T. Suzuki and Y. Ogiba in 1960, which was applicable to the children ranging in age from 1 to 3 years for pure tone audiometry. However, we have still some problems in children with big difference acuity of hearing between both ears. The auther studied to prove these problems. Difference between the binaural summation threshold measured by conditioned orientation reflex audiometry and the threshold of each ear measured by play audiometry was investigated in 82 children, for whom both audiometries could be successfully performed. The difference over $20 \mathrm{db}$ between the both thresholds was frequently observed at all frequencies tested. Therefore, the correlations between the threshold measured by conditioned orientation reflex audiometry and the each threshold of the better ear or the worse ear by play audiometry were separately investigated. Consequently the correlation was more significant in the worse ears than in the better ears, as the significance was $1 \%$.

\section{条件詮索反射聴力測定法 (C.O.R.-Audiometry) の研究}

\author{
新潟大学医学部耳罳咽喉科学教室（主任：㒂 初男教授)

$$
\text { 木 村 光 子 }
$$

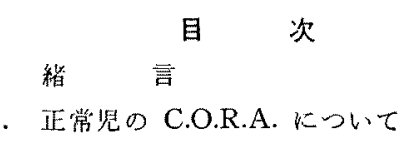
A）装䈯及び測定与法
B) 测定对象
C) 测定成 維
D)小括

II. 難㯖児の C.O.R.A. による闒值の検討
A) 测定方法
B) 测定刘象
C) 泚定成䋐

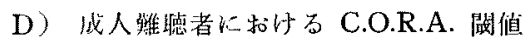
E)小括

III. 難聴罗 C.O.R.A. の一工去
A) 測定方法及び対象
B) 湖定成績
C) 小括

$$
\begin{aligned}
& \text { V. 綜括及び考拈 } \\
& \text { V. 結 } \\
& \text { 交 }
\end{aligned}
$$

\section{緒言}

Dix \& Hallpike ${ }^{1)}$ の Peep show test, Barr ${ }^{2)}$ の数 遊び等で代表される一聯の Play audiometryは, 大略 了才以上の知能正常なる幼児では，成人の Standard audiometry とほぼ同程度の精度で检查することる可能 とした。また近年，3才以下の乳奻㫛についてる膇波聴

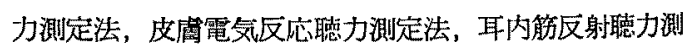
定法，睡眠㭙聴性睡孔反応聴力湘定法等の他覚的検查法 の進捗により，精度の高い聴力測定が可能となつてき た。しかし，淩置が高価なこと，高度な検查技術が必要 なこと等のため，一般臨床榆査法としてはまた問題があ るといえよう．条件反射聴力湘定法 Conditioned Orientation Reflex Audiometry (以下 C.O.R.A. と呼称) は，これらの難点を解決する 検査法のひとつとして， 
1960 年鈴木, 荻場 3４４５５６６７）8）により最初仪発表され たものである：その後いくたの追試 9) 10)11112１3）がな され，3才以下の乳幼児；また 3 才以上でも，難㯖，言 語障害又は知能障害等の合併により Standard audiometry や Play audiometry の適応困難な幼児に対し卓 越せる謖力検查法なることが報告されている。

しかし本法も詳細に検討してみるに，未解決の問題の 介在をみる. 即ち, 武居 ${ }^{14)}$ ，Trenque ${ }^{11)}$ がすでに指摘 している如く難聴児，特に両耳に聴力差つある場合， C.O.R.A: とよつて得られた両耳綜合閾值が，片耳の自 覚的聴力䦭値とどのような関係にあり，何を表示してい るかといら問題がある. 即ち, 正常乳幼胃では精度の高

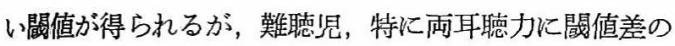
ある場合の測定や，得られた間值の判定に疑義の生ずる 場合がある.

著者も 1962 年以来，本法の追試と臨床的応用を試行 し，同じょうな疑問に遭遇した．武居 ${ }^{14)}$ は斯る問題を C.O.R.A. 閔值の特質である自由音場で二方向に音源を 有する方向音覚を利用して得られた両耳綜合閾值にあり とし，成人を対象としこの問題を詳細に検討し，この解 決策として C.O.R.A. の一改良法を発表したがまだ完成 された方法ではなく多くの問題を内蔵していると結語し ている.

著者は, 斯る問題に対する一つの試案として，これ未 での検査成績にもとづき，片耳づつの自覚閾値と C.O. R.A. 閶値との関係—特に両耳間値差のある場合— 飞集約し， C.O.R.A. 闖値の信頼性と特異性の再検討を 行い, 推計学的処理を行つた結果, いささかの知見を得 たので報告する.

\section{I. 正常児の C.O.R.A. について}

1960 年 5 月鈴木 ${ }^{4)}$ の第 61 回日耳鼻総会における宿題 報告 “他覚的聴力測定” の発表をはじめとして，荻場 5) 6) 7) 8), 武居 ${ }^{9)}$, Trenque et Lafon ${ }^{11)}$, Schröder $u$. Relke ${ }^{10)}$, J.Floux-Guyot ${ }^{12)}$ 等の正常奻览の C.O.R.A. の結果の報告がある.著者も C.O.R.A. の原法に準じて 正常乳幼児の聴力測定を試み, 同時に Startle response audiometry 及び Play audiometry を併用し, その可 能率や閔值を比較検討した。

\section{A）装置及び測定方汒}

測定製置（図 1) は，荻場の变法で 3 筃の独立ボック スからなり, 各ボックスは上下の小室に分れ，両端のボ ックス上部には 8P-X] のスピーカーを設置し, 両切換 スイッチを経てリオン A-1002-D 型オージオメーター
図 1 C.O.R.A. 测定装置

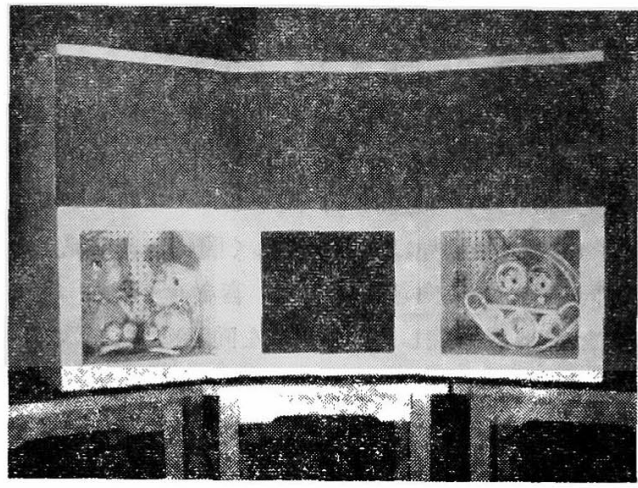

图 23C.O.R.-Audiometry Block Diagram

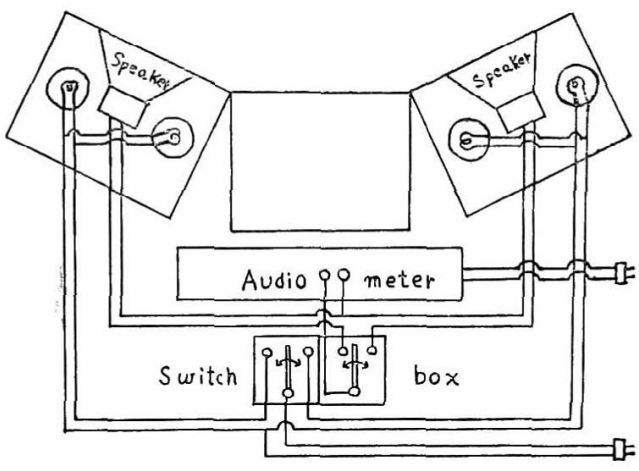

図 3 C.O.R.A. 测定方法

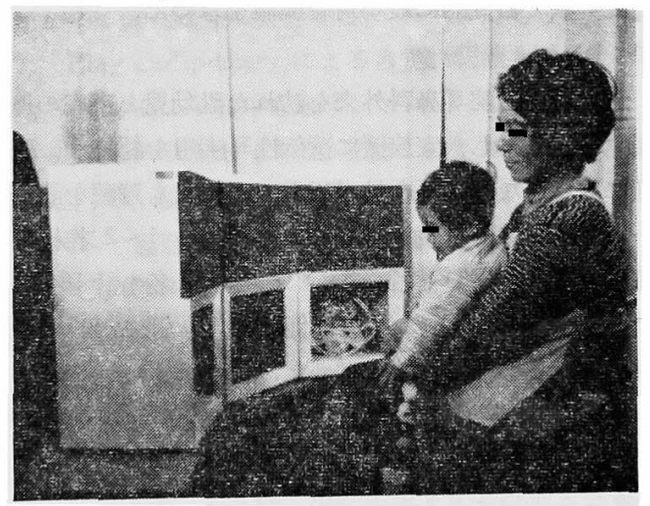

に連結した.

スピーカーの下部には, 各々 2 䈏の人形を入れ, 人形 の体内には豆電球を付し，通電により照明するように装 置した. スピーカー間の距離は $75 \mathrm{~cm}$ で, 被検児は, 両スピーカーの中央から約 $70 \mathrm{~cm}$ 前方の椅子に坐らせ, 被検児の目の高さがボックス中央部になるよう被検児 
の椅子の高さを調節する，測定は新大耳鼻科外来防音室 で，乳幼罗に親しみ易い雾囲気のるとで行った．測定方 法は荻場 5) 6) の原法飞従つた。即与条件形成には 1000 c.p.s. の純音を用い，最初炕閔值上 $40 \sim 50 \mathrm{db}$ と思和机 る強ざ音を左右いら゙れか一方のスピーカーより発振 し，それから䄪 1 秒遅れて，同一ボックスの人形内の電 球をつける。被㭘児は人形が美しく照明されて見えるの で，同方向へ振り向き注目寸る，音を4〜5秒，従つて 照明を3〜4 秒継続したのち両者を同時消し，次に 2 3 秒の間隔を嚂いて，反対側の（音+光）の組み合放せ 刺战を与える、すると，被険児は反対側を振り向きその 万の人形を注視する.同様の操作を $3 \sim 4$ 回不規則に繰 り返すと, 被検児の条件形成ができ上り, 音刺战のみで 反応するようになる，このような条件形成の成立をみて のち, $5 \mathrm{db}$ step の下降法で音の強さを下げて行き，音 だけではつきりした振り向き反応のある点を可聴閵値と 見做し，続いて 2000, 4000, 500c.p.s. の順に闇值を測定 した，周波数の变る都度䦪值上 40 50db の音で（音+ 光）の強化刺钱を施行した，㭘查時間は平均 5〜6分， 最高 12 分であつた。な特，Startle response audiometry は鈴木一花岡の方法 ${ }^{3)}$ 亿従い, Play audiometry は片耳づつレシーバーを装着し，Barr の方法に準じた 2〜3の遊びを用意したが，中でる効果的であつたのは， 音の出る玩具（ウッドブロック，カスタネット，鈴）に 上る遊びであつた，また対照の成人では，同一装固に上 り上舁法で自覚的に最小可聴間值を求めた。

\section{B) 対 潒}

新大附属病院耳粤科外来を訪机大乳奻児之市内の保育 園胃を対象とし，家族歴に遗伝性耳涘虫を認めず，既往 歴に耳疾患なく，耳所見が正常で，家人も蜼聴を認めな い者を正常児と見做し，1才未満 24 名，1〜2才末满 29 名，2〜3才満 35 名，3〜 5 才未满 98 名の計 186 名に C.O.R.A. を施行した，更に健康成人 5 例について子対 照として最小可聴閾値を求めた。

C) 測定成績

1) 測定可能率：

各年令段陼による測定可能の割合は，表】に示した。 湘定可能とは初回検查で，1000，2000，4000，500c.p.s. の4純音すべてについて測定できたものを謂い，一部可 能とは，4 周波数のうち一部湘定可能. 不能とは，す心 ての周波数で測定できなからたものである．可能率をみ ると，1才未满 $29 \% ， 1 \sim 2$ 才未满 $83 \% ， 2 \sim 3$ 才未满 88 $\%$ ，3〜5才末满 $61 \%$ で，1〜3才未淈では $80 \%$ 以上の
表 1 各年令段階による测定可能の割合 (正常愳)

\begin{tabular}{|c|c|c|c|c|c|}
\hline 年令 & 可 能 & $\begin{array}{ll}\text { 可 部 } \\
\text { 能 }\end{array}$ & 不 能 & 計 & 可能率 \\
\hline 1 才末涌 & 7名 & 11名 & 6名 & 24名 & $29 \%$ \\
\hline $1 \sim 2$ & 24 & 3 & 2 & 29 & 83 \\
\hline $2 \sim 3$ & 31 & 2 & 2 & 35 & 88 \\
\hline $3 \sim 5$ & 60 & 27 & 11 & 98 & 61 \\
\hline
\end{tabular}

表 2 检查法による测定可能率の比较 (正常児)

\begin{tabular}{|c|c|c|c|c|c|}
\hline 今命 & $\begin{array}{l}\text { 被検 } \\
\text { 胃数 }\end{array}$ & C.O.R.A. & $\begin{array}{c}\text { Startle- } \\
\text { Response- } \\
\text { Audio- } \\
\text { mretry }\end{array}$ & $\begin{array}{l}\text { Play- } \\
\text { Audio- } \\
\text { mety }\end{array}$ & $\begin{array}{l}\text { Standard- } \\
\text { Audio- } \\
\text { metry }\end{array}$ \\
\hline $\begin{array}{ll}1 & \text { 釆 } \\
\text { 未 }\end{array}$ & 24名 & $29 \%$ & $77 \%$ & $0 \%$ & $0 \%$ \\
\hline $1 \sim 2$ & 29 & 83 & 88 & 13 & 0 \\
\hline $2 \sim 3$ & 35 & 88 & 43 & 57 & 29 \\
\hline $3 \sim 5$ & 98 & 61 & 10 & 90 & 37 \\
\hline
\end{tabular}

高い可能率を示しているが，3才以上では $61 \%$ と可能 率が減少する，因み汇，同時行行つた他の检查法の可能 率と比較してみると表 2 亿示す如くで，1才未满では C.O.R.A.よりも Startle response audiometry の可能 率が高く，3才以上では Play audiometry が90\% と C.O.R.A. K比して高い可能率を示している，即ら C. O.R.A. の対象としては $1 〜 3$ 才が適していると謂える.

2) 正常巟の C.O.R.A. 可聴䦪値:

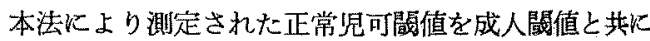
表 3，図4亿示す，測定闒值はいら゙れも正常成人10名 の閖值で補正したものであり（）内は95\%信頼限界 示す，各周波数の年令別綜合平均閔値は，1才末满 $24.7 \mathrm{db} ， 1 \sim 2$ 才未満 $18.7 \mathrm{db} ， 2 \sim 3$ 才未満 $18.0 \mathrm{db} ， 3 \sim 5$

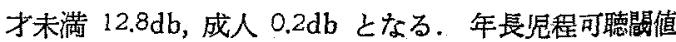
の分散は低く，精度は高くなり，年令增加之共纪成人可

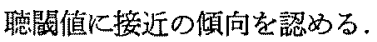

3) 自覚的聴力闌値との比較:

C.O.R.A. と Play audiometry $の$ 雨者が可能であつた 30 例について閔值を比較した（対象例はいづれも Play audiometry の左右闖值差は $10 \mathrm{db}$ 以内であつた)，表 4 は周波数別にみた Play audiometry 雨耳平均闒值と C.O.R.A. 閔值の比較で， $\pm 5 \mathrm{db}$ 以内での一致率は 1000 c.p.s. $90 \%, 2000$ c.p.s. $77 \%$, 4000 c.p.s. $81 \%, 500$ c.p.s. $82 \%$ であり，全例が $\pm 15 \mathrm{db}$ 以内であつた。 
表 3 各年令别正常児最小可聪閶値 (平均閧值)

\begin{tabular}{|c|c|c|c|c|c|c|}
\hline 年令 & $\begin{array}{l}\text { 被檢 } \\
\text { 垐数 }\end{array}$ & 500 c.p.s. & $\begin{array}{l}\text { c.p.s. } \\
1000\end{array}$ & $\begin{array}{l}\text { c.p.s. } \\
2000\end{array}$ & ${ }_{4000}^{\text {c.p.s. }}$ & 平均 \\
\hline $\begin{array}{l}1 \text { 才 } \\
\text { 未满 }\end{array}$ & $\begin{array}{l}\text { 名 } \\
7\end{array}$ & $\begin{array}{r}\mathrm{db} \\
21.0 \\
(\mathrm{~m} \pm 3.9)\end{array}$ & $\begin{array}{r}\mathrm{db} \\
26.5 \\
(\mathrm{~m} \pm 4.2)\end{array}$ & $\begin{array}{r}\mathrm{db} \\
24.2 \\
(\mathrm{~m} \pm 4.7)\end{array}$ & $\begin{array}{r}\mathrm{db} \\
27.0 \\
(\mathrm{~m} \pm 2.8)\end{array}$ & 24.7 \\
\hline $1 \sim 2$ & 24 & $\begin{array}{c}16.6 \\
(m \pm 2.6)\end{array}$ & $\begin{array}{c}18.3 \\
(m \neq 1.9)\end{array}$ & $\begin{array}{c}19.7 \\
(\mathrm{~m} \pm 3.0)\end{array}$ & $\mid \begin{array}{c}20.0 \\
(m \pm 3.2)\end{array}$ & 18.7 \\
\hline $2 \sim 3$ & 31 & $\begin{array}{c}16.3 \\
(\mathrm{~m} \pm 2.1)\end{array}$ & $\begin{array}{c}17.5 \\
(\mathrm{~m} \pm 2.2)\end{array}$ & $\begin{array}{c}18.4 \\
(\mathrm{~m} \pm 2.7)\end{array}$ & $\begin{array}{c}19.8 \\
(m \pm 2.6\end{array}$ & 18.0 \\
\hline $3 \sim 5$ & 60 & $\left(\begin{array}{c}9.3 \\
(\mathrm{~m} \pm 1.2\end{array}\right)$ & $\begin{array}{c}12.8 \\
(\mathrm{~m} \pm 1.8)\end{array}$ & $\begin{array}{c}11.4 \\
(\mathrm{~m} \pm 2.6)\end{array}$ & $\left.\begin{array}{c}17.8 \\
(\mathrm{~m} \pm 1.9\end{array}\right)$ & 12.8 \\
\hline 成人 & 5 & $\left.\begin{array}{c}-0.5 \\
(\mathrm{~m} \pm 3.2\end{array}\right)$ & $\begin{array}{c}0 \\
(\mathrm{~m} \pm 2.8)\end{array}$ & $\begin{array}{c}0 \\
(\mathrm{~m} \pm 4.2\end{array}$ & $\begin{array}{r}1.2 \\
(\mathrm{~m} \pm 3.1)\end{array}$ & 0.2 \\
\hline
\end{tabular}

（）内は $95 \%$ 信頼限界

図 4 平均閵值の年令別推移（正常照）

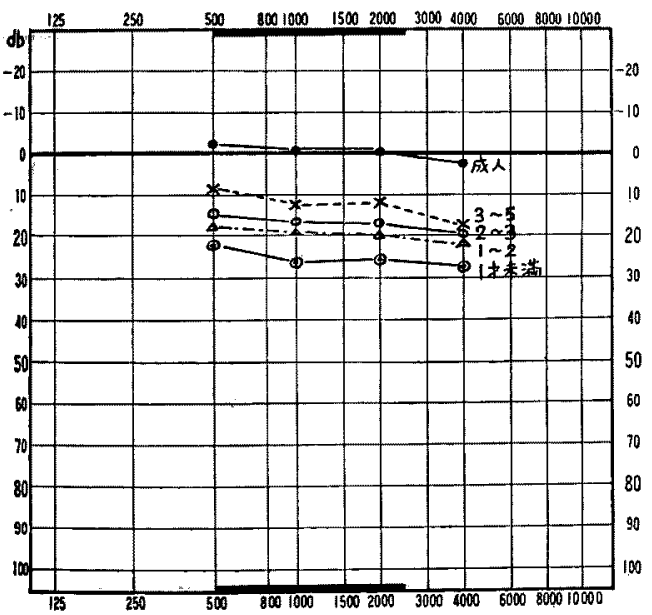

c.p.s.

表 4 自覚的聴力閵値との比較 (正常胃) (Play-A. 平均值一C.O.R.A. 閶値)

\begin{tabular}{|c|c|c|c|c|}
\hline $\mathrm{db} ل^{\text {c.p.s. }}$ & 500 & 1000 & 2000 & 4000 \\
\hline-15 & O名 & ○名 & O名 & 1名 \\
\hline-10 & 1 & 1 & 2 & 0 \\
\hline-5 & 3) & 3) & 2) & 5 \\
\hline 0 & $7\} 82 \%$ & $939 \%$ & $11\} 77 \%$ & $8381 \%$ \\
\hline+5 & 13) & 15) & 10) & 9) \\
\hline+10 & 2 & 2 & 4 & 1 \\
\hline+15 & 2 & 0 & 1 & 3 \\
\hline
\end{tabular}

表 5 颉査，再湌査間の閾傎变動（正常児） (再検查値一初回険查值)

\begin{tabular}{|c|c|c|c|c|c|c|c|}
\hline c.p.s. & -15 & -10 & -5 & 0 & +5 & +10 & +15 \\
\hline 500 & O名 & O名 & 3名 & 8名 & 6名 & 2名 & O名 \\
\hline 1000 & 0 & 1 & 4 & 9 & 4 & 1 & 0 \\
\hline 2000 & 0 & 0 & 4 & 5 & 8 & 2 & 0 \\
\hline 4000 & 0 & 1 & 3 & 7 & 6 & 2 & 0 \\
\hline$\%$ & \multicolumn{7}{|c|}{$89 \%$} \\
\hline & & & & $\begin{array}{l}1 \sim 2 \\
2 \sim 3 \\
3 \sim 5\end{array}$ & $\begin{array}{l}9 \\
8 \\
2 \\
2\end{array}$ & & \\
\hline
\end{tabular}

4) 検查，再検查間の閏値変動:

初回検㚗から1 2 週間の間滆を牧いて 再検査のでき た19 例の内訳は，1〜2才末満9 例，2〜3才未満8例， 3〜 5 才未渵 2 例で, 表 5 は初回測定值と再検査值との 比較で全体の $89 \%$ が士5db 以内で一致している，年長 罗では C.O.R.A. 雨检査不能例が增加し，代りに初回不 能であつた Play audiometry が可能になつた例が認め b九た。

D) 小 括

1) C.O.R.A.は，1才以上 3 才未満の 奻肾に適応す 3 .

2）正常児の C.O.R.A. 閶値は高昌部潮傾型で，年令

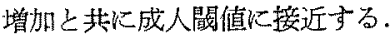

3) Play audipmetry Kよる自覚的闌值とは，士5db 以内 $83 \%$ の高い一致率安示す.

4) 再検查可能例の䦪值の变動は，全体の89\%が士 $5 \mathrm{db}$ 以内で, 閏値の精度が高い。

\section{II. 難聴児の C.O.R.A. による䦭値の検討}

前章で C.O.R.A.は1〜3才に適応し，信頼性ある堆波 数別測定閧值が得られることがわかつた，しかし，緒言 に述べた如く難聴児——特に左右聴力差のある場合一 にあつては湘定閾值をどのよらに評価するかの問題が分 入してくるので，正常児の場合と同一に諭ずることはで きない，そこで，著者はこれまでの测定結果を再検討 し, 推計学的処理を加党, 難聴児の C.O.R.A. 䦪值の信 頼性と特異性を検討した.

A) 湘定対象

対象は，昭和 37 年 4 月から 40 年 3 月までの間，新大 附属病院耳舅科外来を難聴又は，言語障書を主訴として 訪れ，C.O.R.A.を施行した222名である（表7）。その 
表 6 娭查対象（play-A. と C.O.R.A 両者可能例)

\begin{tabular}{c|c|c|c}
\hline 年令性別 & 男 & 女 & 計 \\
\hline $2 \sim 3 才$ & 1 名 & 0名 & 1 名 \\
$3 \sim 4$ & 4 & 4 & 8 \\
$4 \sim 5$ & 12 & 8 & 20 \\
$5 \sim 6$ & 11 & 12 & 23 \\
6 才以上 & 15 & 15 & 30 \\
\hline 䛨 & 43 & 39 & 82
\end{tabular}

うち C.O.R.A. 閔值の検討対象はレシーバーによる片耳 づつの Play audiometry が同時に可能で，確実に閔值 測定のできた 82 例である. 82 例の年令別，性別分布は 表 6 に示したが，2〜3才未満 1 名，3〜4才淦 8 名，4 ～5才未満 20 名，5６才未満 23 名，6才以上 30 名で ある。

B）湘定方法

装置及び測定方法は前章に詳述した．条件形成の際， 中等度，高度難聴児にあつては低音部に残聴のある例の 多い、䎁実から，500c.p.s. を使用した例もあつた。

険查順序は C.O.R.A. を最初に，次いで Startle response audiometry 又は Play adiometry；次いで他検 查の䐓に行つた. Startle response audiometry は前章 のそれと同じく動物の擬音を使用，Play audiometry はレシーバーに上る片耳づつの測定で Barr の方法に潐 したが音の出る玩具による遊びが正常児に括ける以上に 一層効果的であつた。

C) 測定成續

1) 湘定可能率:

各年令別 C.O.R.A. 可能率怔, 表 7 亿示す如く 1 4 才未満がもつとも高い可能率を示している. 正常児の場 合と異つて，4〜5才未満 74\%，5６才未満 83\%，6才

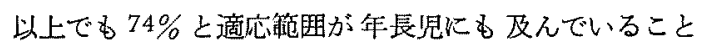
が判る. 閖值測定が全く不能であつた 34 例の原因㳖表 8 の如くで，心的因子や精神発澾状態が関与することが 充分考党られた. 同時に行つた他の梌查方法との測定可 能率の比較は表 9 の如くである.

\section{2) C.O.R.A. 閾值}

C.O.R.A. 閔値と Play audiometry 両耳平均闎値之 を各祘波数別に分けて比較し，両者の差の分散を表 10 に示す． $\pm 5 \mathrm{db}$ 以内の一致率恓各周波数共 40 50\% で ある. 次で, 左右㯖力差 $20 \mathrm{db}$ 以上の 10 症例完とり出
表 7 各年令段階による測定可能の剖合 （難聴又は言語障害児）

\begin{tabular}{|c|c|c|c|c|c|}
\hline 年令 & 可 能 & 一部可能 & 不 能 & 計 & 可能率 \\
\hline 1 才末㵽 & 1名 & O名 & O名 & 1名 & $100 \%$ \\
\hline $1 \sim 2$ & 21 & 1 & 0 & 22 & 96 \\
\hline $2 \sim 3$ & 32 & 3 & 1 & 36 & 89 \\
\hline $3 \sim 4$ & 28 & 1 & 3 & 32 & 86 \\
\hline $4 \sim 5$ & 31 & 1 & 10 & 42 & 74 \\
\hline $5 \sim 6$ & 30 & 0 & 6 & 36 & 83 \\
\hline 6 才以上 & 39 & 0 & 14 & 53 & 74 \\
\hline 訪 & 182 & 6 & 34 & 222 & 82 \\
\hline
\end{tabular}

表 8 C.O.R.A. 不能症侧 (難聴, 言語障害児)

\begin{tabular}{|c|c|c|}
\hline 令 & $\mid$ 例数 $\mid$ & 原 \\
\hline 2〜3才未満 & 1 & 恐怖心（音） \\
\hline $3 \sim 4$ & 3 & 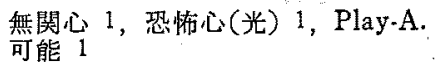 \\
\hline $4 \sim 5$ & 10 & 恐怖心(光) 2, Play-A 可能 8 \\
\hline $5 \sim 6$ & 6 & Play-A 可能 6 \\
\hline 6 术以上 & 14. & $\begin{array}{l}\text { Psychose 1, Startle R.A. 可能 } 1 \text {, } \\
\text { Play-A. 可能 } 12\end{array}$ \\
\hline
\end{tabular}

表 9 測定法比よる測定可能涪の比敕 (難聴, 言語娈害紧)

\begin{tabular}{|c|c|c|c|c|c|}
\hline 年 令 & $\begin{array}{l}\text { 被検 } \\
\text { 罗数 }\end{array}$ & C.O.R.A. & $\begin{array}{c}\text { Startle } \\
\text { R.-A. }\end{array}$ & Play-A. & $\begin{array}{l}\text { Stan- } \\
\text { dard-A }\end{array}$ \\
\hline 1 才未菛 & 1名 & $100 \%$ & $100 \%$ & $0 \%$ & $0 \%$ \\
\hline $1 \sim 2$ & 22 & 95.5 & 82 & 0 & 0 \\
\hline $2 \sim 3$ & 36 & 89.0 & 33.4 & 2.8 & 0 \\
\hline $3 \sim 4$ & 32 & 87.5 & 18.8 & 28.0 & 0 \\
\hline $4 \sim 5$ & 42 & 74.0 & 11.9 & 64.5 & 2.4 \\
\hline $5 \sim 6$ & 36 & 83.4 & 5.6 & 83.4 & 2.8 \\
\hline 6 才以上 & 53 & 73.6 & 3.8 & 71.8 & 20.8 \\
\hline 計 & 222 & 82.0 & 20.7 & 47.3 & 5.9 \\
\hline
\end{tabular}


表 10 自覚的聴力閶值との比踤 (play·A. 平均値-C.O.R.A. 閶值)

\begin{tabular}{|c|c|c|c|c|}
\hline $\mathrm{db}$ & 500 & 1000 & 2000 & 4000 \\
\hline 35以下 & 2 & & 1 & \\
\hline 30 & 1 & 1 & 3 & 3 \\
\hline 25 & 6 & 1 & 7 & 5 \\
\hline 20 & 5 & 4 & 6 & 4 \\
\hline 15 & 9 & 7 & 16 & 9 \\
\hline 10 & 18 & 10 & 11 & 16 \\
\hline-5 & 16) & 18 & $23)$ & 19 \\
\hline 0 & $11\} 45 \%$ & $17\} 40 \%$ & $6\} 40 \%$ & $43 \%$ \\
\hline$\overline{+5}$ & 10) & 15) & 4) & 10) \\
\hline 10 & 3 & 4 & 2 & 2 \\
\hline 15 & 0 & 2 & 0 & 4 \\
\hline 20 & 1 & 2 & 0 & 0 \\
\hline 25 & & 0 & 3 & 1 \\
\hline 30 & & 1 & & 2 \\
\hline 35 以上 & & & & \\
\hline
\end{tabular}

Ex

症 例 1

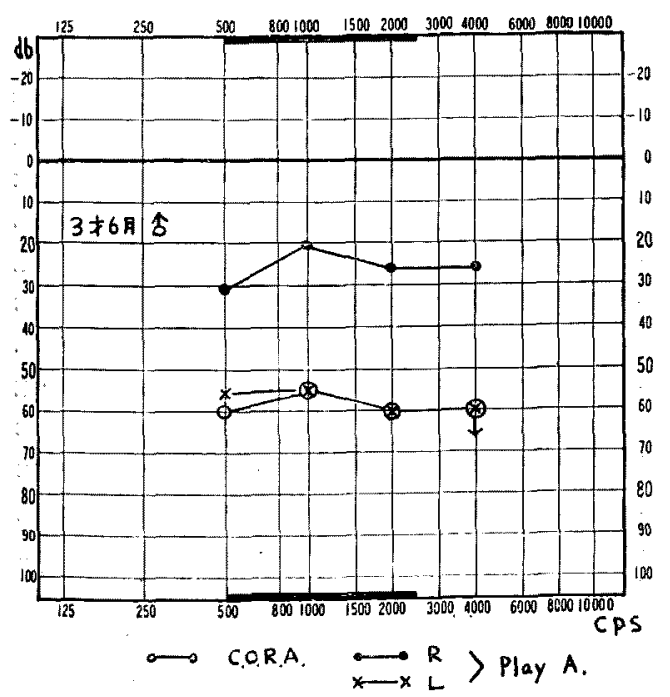

L， play audiometry 䦪值の両耳平均でなく，良・瑟 聴耳各别個の play audiometry 閾值と C.O.R.A. 䦪值 との関係を見ると，图5に示与如く，Play audiomtry の悪聴耳闒値と C.O.R.A. 闒值が一致むたは，近接して いる例

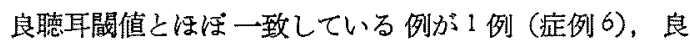
聴耳闇值と 悪聴耳閶値の中間值を 示している 例が 1 例 (佂例 10)であつた.

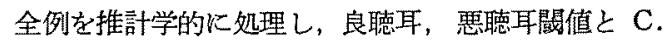
O.R.A. 閾值との相関々係を見た。即ち，対象 82 例を 乱数表を用いて 2 群に分け， 1 群は良聴耳闒值と C.O. R.A. 䦪値，他群恃悪聴耳閔値と C.O.R.A. 䦪值とし， 各々，相関図，相関俰数を求めた（図6)、相関係数は 1000c.p.s. では良㯖耳 0.727 ，悪聴耳 $0.982 ， 2000$ c.p.s. では良聴耳 0.671 ，悪㯖耳 $0.932 ， 4000$ c.p.s.では良㯖耳 0.695 , 悪㯖耳 0.923 , 500c.p.s では良聴耳 0.500 , 悪聴 耳0.877であつた．各周波数別の良悪両者の相関係数間 の相関比は 1000c.p.s で6.32, 2000c.p.s. で 3.75, 4000

5

症 例 2

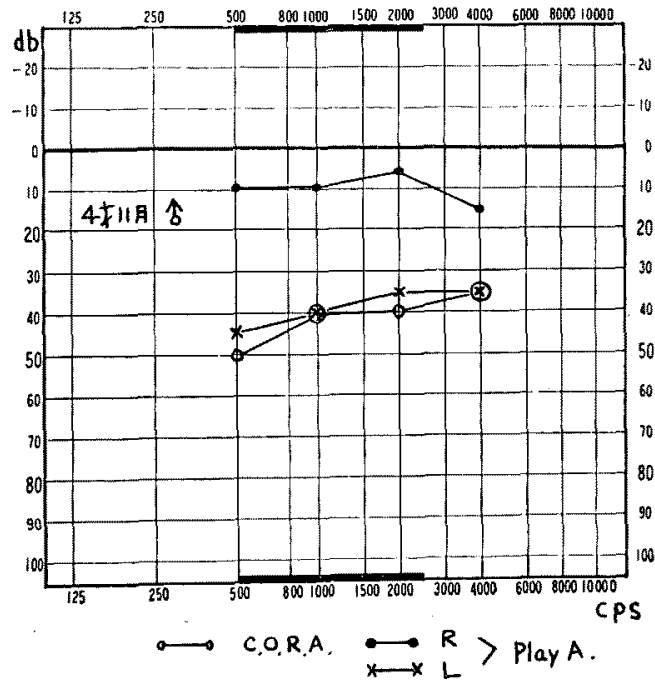



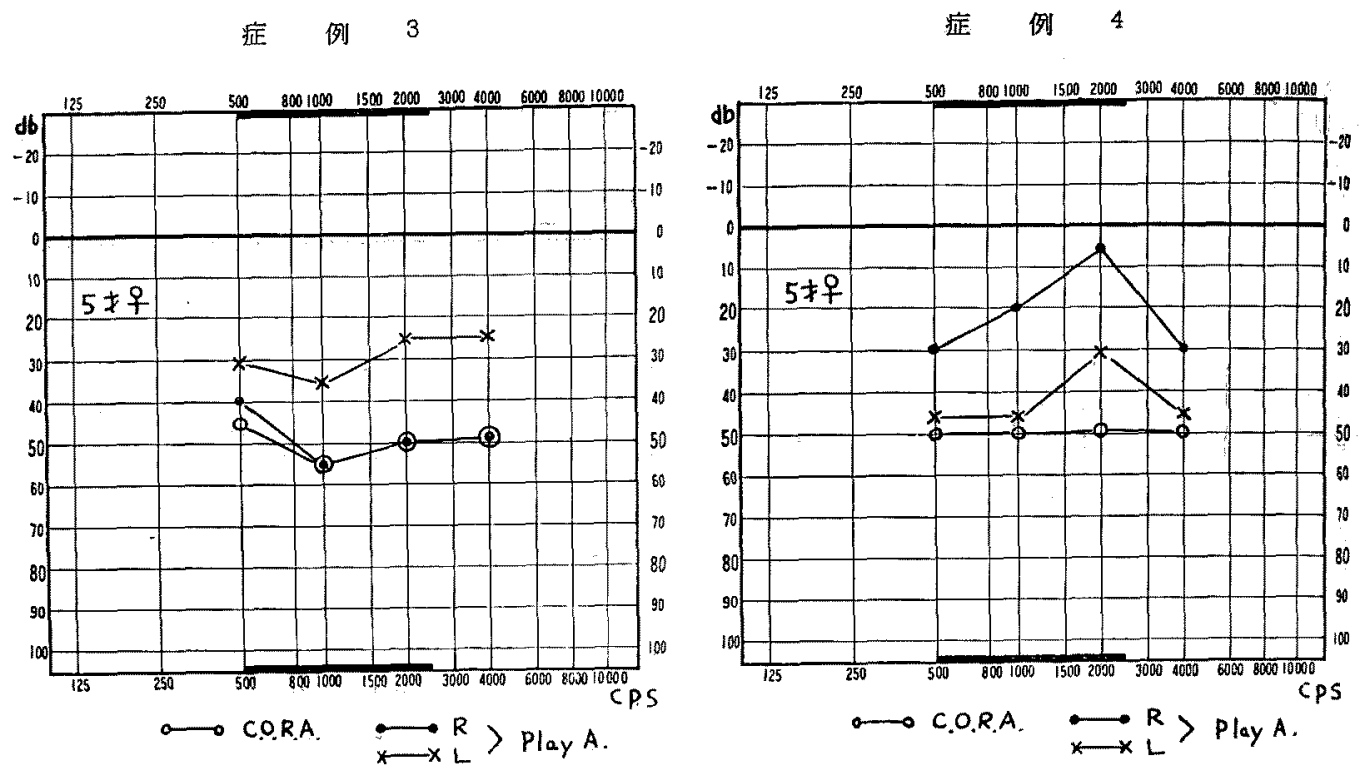

症例 5

症例 6
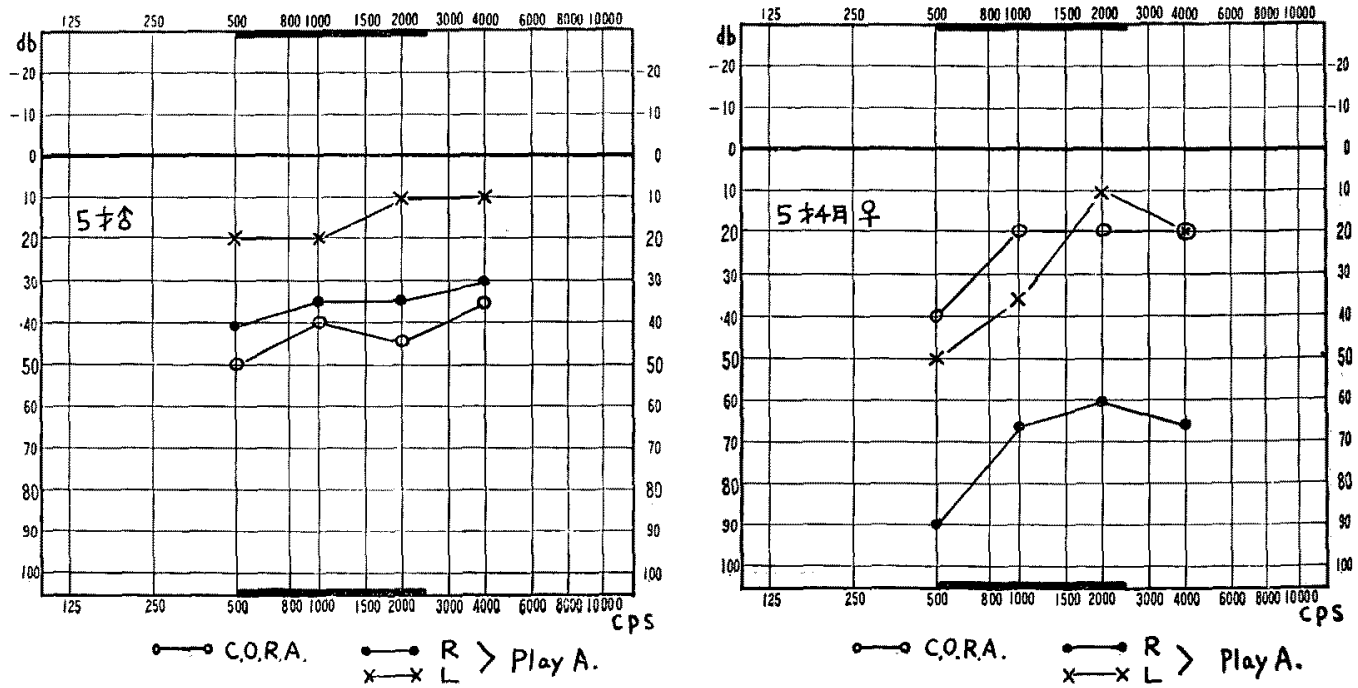

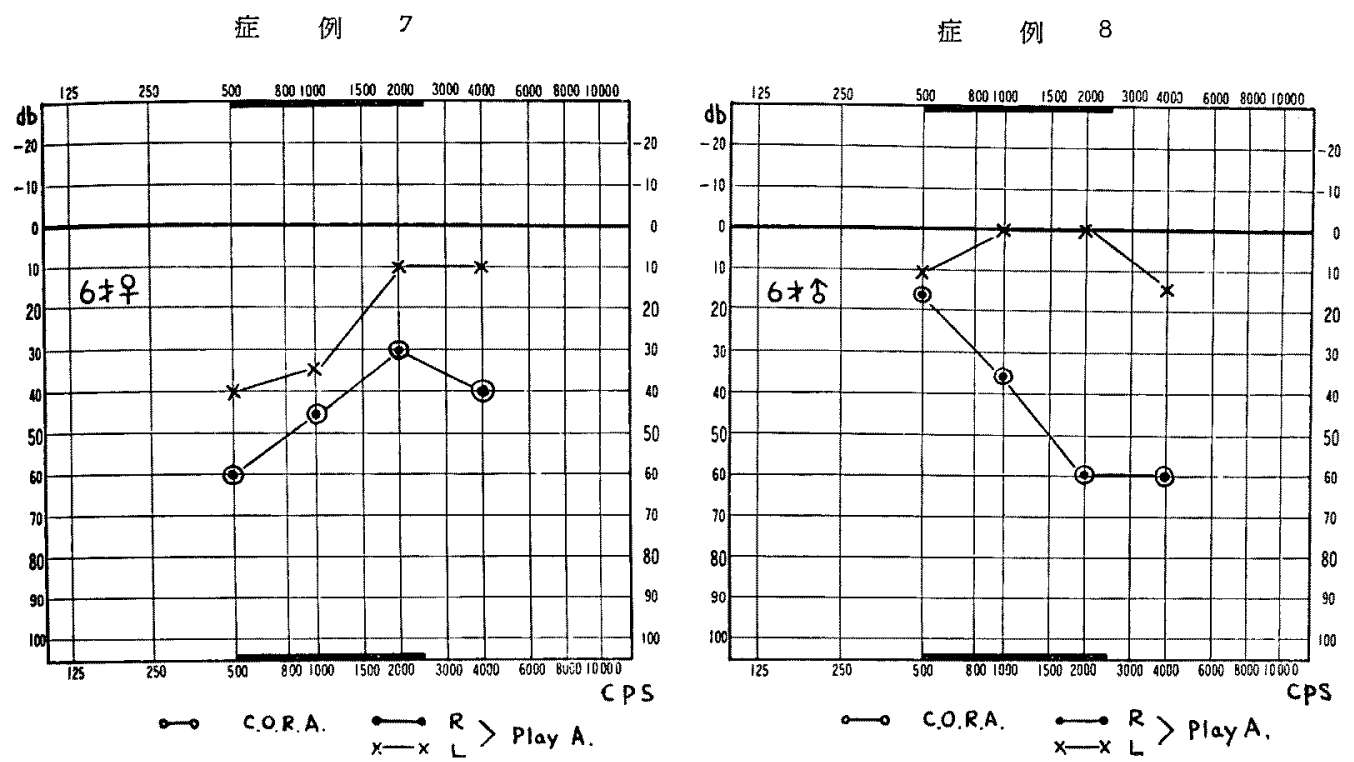

症 例 9

症例 10
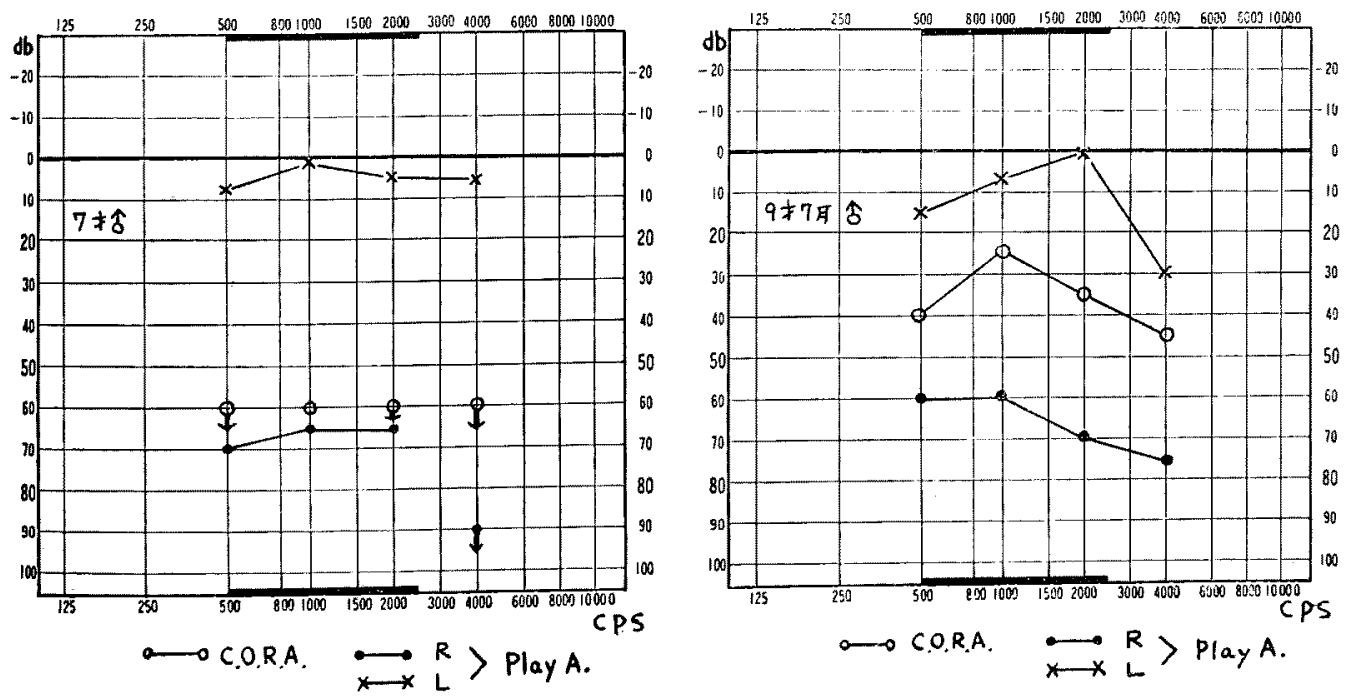
图 6 C.O.R.-A 閶值と play-A 閶値の相関図

I 1000 c.p.s.

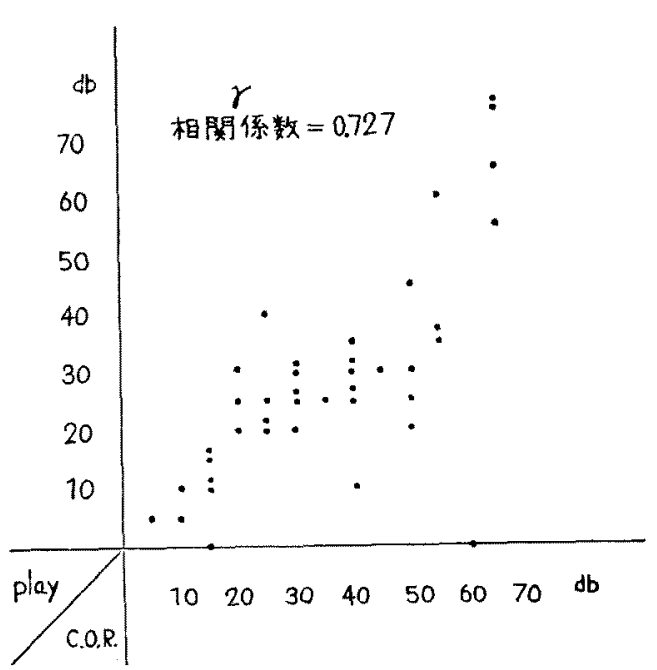

良 聴 耳 -41 例一

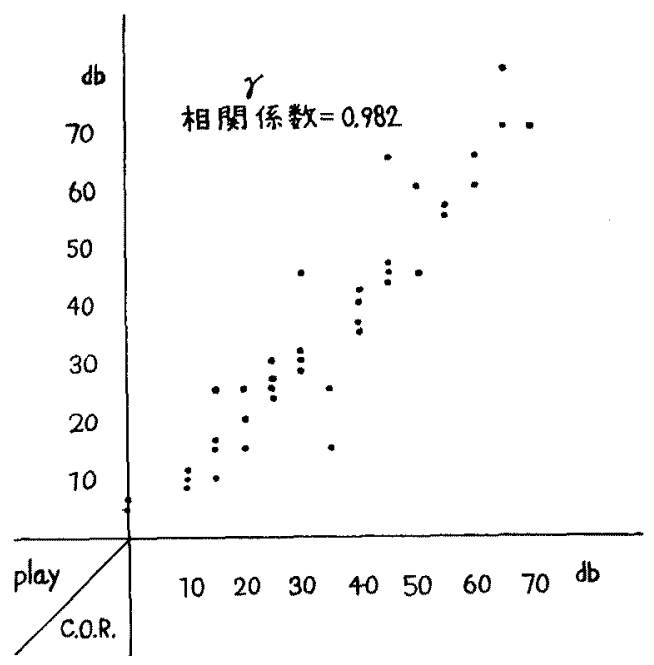

恶 德 耳 -41 例一

II 2000 c.p.s.

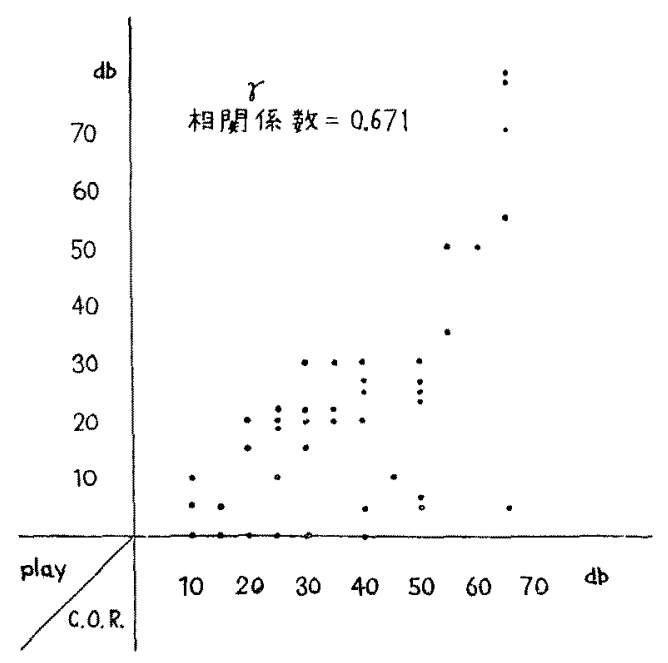

良聴 兮 -41 例一

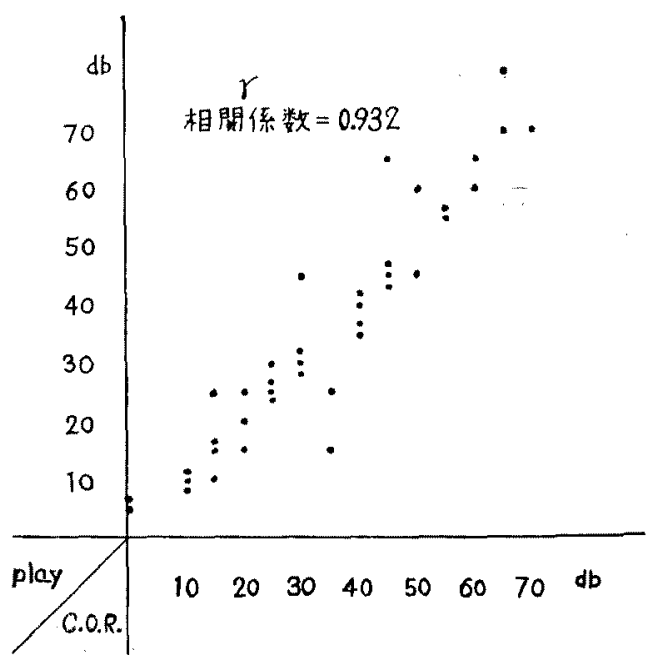

瑟 聴 耳 -41 例一 
III 4000 c.p.s.

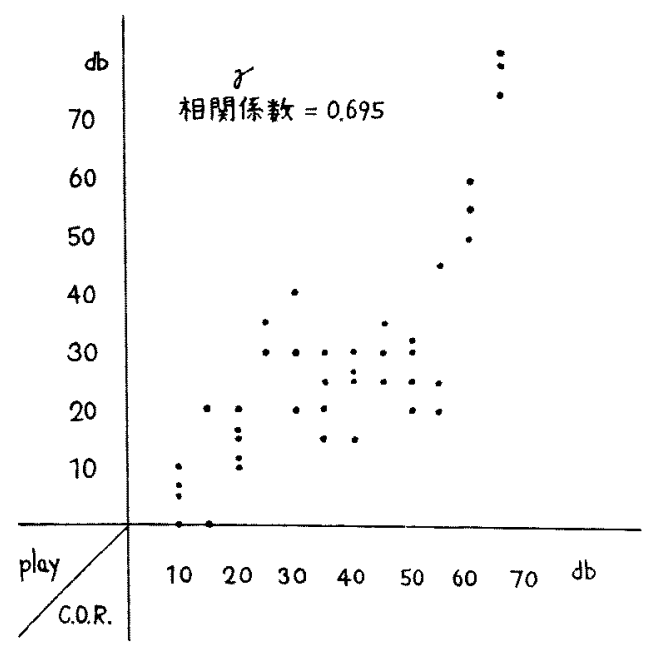

良 缌耳 -41 例一

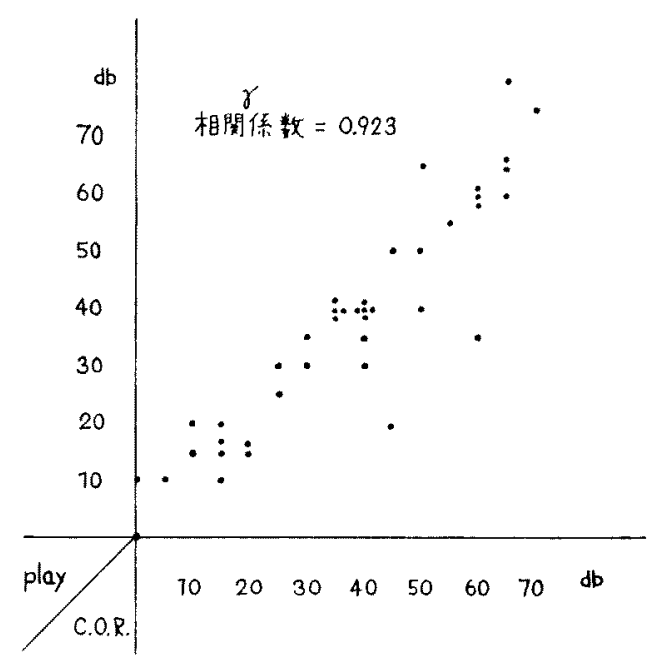

瑟 聴 耳 -41 例一

IV 500 c.p.s.

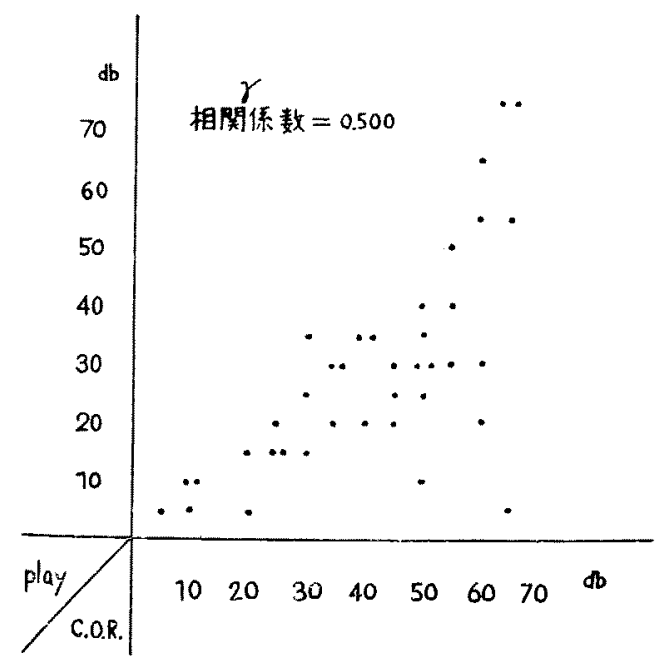

主 聴耳-41例一

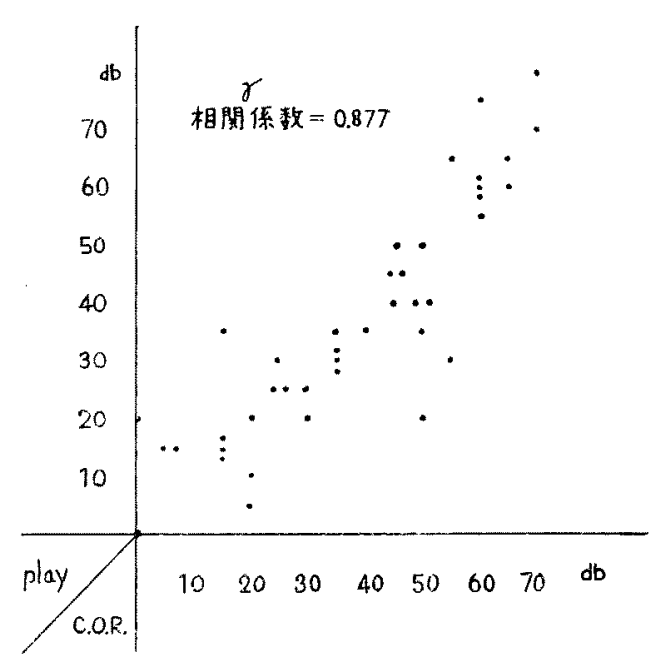

䔡 聴 -41 例一 
表 11 相関倸数及び相関比

\begin{tabular}{c|c|c|c|c}
\hline 耳c.p.s. & 500 & 1000 & 2000 & 4000 \\
\hline \hline 良㯖耳 & 0.500 & 0.727 & 0.671 & 0.695 \\
覀 聴耳 & 0.877 & 0.982 & 0.932 & 0.923 \\
\hline 相 関比 & 3.53 & 6.32 & 3.75 & 3.28
\end{tabular}

c.p.s. で 3.28 , 500 c.p.s. で 3.53 となり，各周波数共推 計学的に 1\% 以内の危俟率で，覀聴耳閏值の方が良鲾耳 䦪より C.O.R.A. 䦪值との相関が強いと謂える。即ら， 左右聴力差のある奻児では，C.O.R.A. 原法では覀聴耳 の聴力を測定していることが多いと謂える．及，周波数 別による特異性は認められない（表 11）。

D) 成人難聴者における C.O.R.A. 闒值

1) 湘定対象:

すでに Standard audiometryにより両側とも㯖力测 定の行われている難㯖成人 18 名である（表 $12 の I: 10$ 例, II:8例)

2) 測定方法:

C.O.R.A. 装置，頭位等は幼児の場合と同一条件とし， 振り向き反射のかかりに自覚指示を指標とした，睍定は 闘值下の強さから上昇法で同一レベルの音について7 回，左右任意心発振し，聞えた合図之同時に方向を指示 させた．聞光ても方向不明の場合は不明とし，7回とも 正確に方向指示のできたレベルを C.O.R.A. 閾值と見 なした. $1000,4000,500$ c.p.s. の順で测定を行つた。

3) 测定成績:

图7 の症例 1 及び，2はその例示である. 症例1は左 伝音難聴 (右 $10 \mathrm{db}$, 左 $55 \mathrm{db}, 1000 \mathrm{c}$.ps.) であるが C. O.R.A. (1000c.p.s.) では $20 \mathrm{db}$ で音は聞えたが方向不 明，60db ではじめて 7 回共音源方向を正しく指示でき た. 症例 2 は左感音難聴（右 $5 \mathrm{db}$, 左 $45 \mathrm{db}, 1000$ c.p.s.) で C.O.R.A. (1000c.p.s.) では $5 \mathrm{db}$ から良聴耳側で聞 えたが，30db 以上ではすべての音が中央から聞えると 答えた。

18 例を゙をめてみると表 12 (I，II）に示す如くで， 左右聴力差のある症例の約 $70 \%$ が瑟聴耳閩值附近で音 源方向を正答できた。しかし同一人でる周波数を変える と必らずしも同一の反応を示さず，一定の傾向を認め得 なかつた。また，悪聴耳闒値上で音源方向を良聴耳側に のみ指示する症例（1の1），一側辟ですべて良耳側か ら聞えるとする症例（\|の7)，悪聴耳閶值上ですべて

\section{図 7}

症例 139 才早 左・伝音難㯖

1000c.p.s. レシーバー自営闘值 R. $10 \mathrm{db}$ L. $55 \mathrm{db}$

\begin{tabular}{|c|c|c|c|c|c|c|c|}
\hline $\mathrm{db} \mathrm{D}^{\mathrm{i}}$ & $\mathrm{Rs}$ & L & $\mathbf{R}$ & L & L & $\mathrm{R}$ & L \\
\hline 10 & & & & & & & \\
\hline 20 & $\triangle$ & $\triangle$ & $\triangle$ & $\triangle$ & $\triangle$ & $\triangle$ & $\triangle$ \\
\hline 30 & $\Delta$ & $\triangle$ & 0 & $\Delta$ & $\triangle$ & 0 & $\Delta$ \\
\hline 40 & 0 & $x$ & 0 & $x$ & 0 & $x$ & $x$ \\
\hline 50 & 0 & $\Delta$ & $\mathrm{O}$ & 0 & 0 & 0 & 0 \\
\hline 60 & 0 & 0 & 0 & 0 & 0 & 0 & 0 \\
\hline
\end{tabular}

500c.p.s. レシーバー自覚闒值 R. $10 \mathrm{db}$ L. $60 \mathrm{db}$

\begin{tabular}{l|ccccccc}
\hline 10 & $\Delta$ & $\Delta$ & $\Delta$ & & & & \\
20 & $\Delta$ & $\Delta$ & $\Delta$ & $\Delta$ & $\Delta$ & 0 & $\times$ \\
30 & $O$ & $\times$ & 0 & $\times$ & $\times$ & 0 & $\times$ \\
40 & 0 & $\times$ & 0 & $\times$ & $\times$ & 0 & $\times$ \\
50 & 0 & 0 & 0 & 0 & 0 & 0 & 0 \\
60 & 0 & 0 & 0 & 0 & 0 & 0 & 0
\end{tabular}

○正しく方向指示 $\times$ 聞えるが反対方向指示 $\triangle$ 聞えるが方向不明

例 241 才古 左・感音難聴

1000 c.p.s. レシーバー自営閔值 R. $5 \mathrm{db}$ L. $45 \mathrm{db}$

\begin{tabular}{|c|c|c|c|c|c|c|c|}
\hline $\mathrm{db} \searrow^{\text {意源 }}$ & $\mathrm{R}$ & $\mathrm{R}$ & L & $\mathbf{R}$ & $\mathrm{L}$ & $\mathrm{L}$ & $\mathrm{R}$ \\
\hline 5 & 0 & 0 & $x$ & 0 & $x$ & $x$ & 0 \\
\hline 10 & 0 & $\triangle$ & $x$ & $\triangle$ & $\triangle$ & $\triangle$ & $\Delta$ \\
\hline 20 & 0 & 0 & $x$ & 0 & $x$ & $x$ & 0 \\
\hline 30 & $\triangle$ & $\triangle$ & $\triangle$ & $\Delta$ & $\triangle$ & $\triangle$ & $\Delta$ \\
\hline 40 & & & & & & & \\
\hline 50 & \multirow{2}{*}{\multicolumn{7}{|c|}{ 全て中央から聞えるよらに感ずる。 }} \\
\hline 60 & & & & & & & \\
\hline
\end{tabular}

4000 c.p.s. レシーパー自覚闑值 R. $5 \mathrm{db}$ L. $60 \mathrm{db}$

\begin{tabular}{l|ccccccc}
15 & $\Delta$ & $\Delta$ & $\Delta$ & & & & \\
20 & $\Delta$ & $\triangle$ & $\Delta$ & $\triangle$ & $\Delta$ & & \\
30 & $\times$ & $\Delta$ & $\Delta$ & 0 & $\Delta$ & $\Delta$ & 0 \\
40 & 0 & $\Delta$ & $\Delta$ & 0 & $\Delta$ & $\Delta$ & 0 \\
50 & 0 & $\Delta$ & 0 & $\Delta$ & 0 & 0 & 0 \\
60 & 0 & 0 & 0 & 0 & 0 & 0 & 0
\end{tabular}




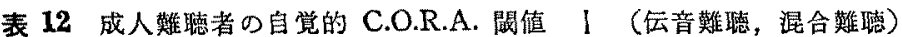

\begin{tabular}{|c|c|c|c|c|c|c|c|}
\hline \multicolumn{2}{|c|}{ c.p.s. } & \multicolumn{2}{|c|}{500} & \multicolumn{2}{|c|}{1000} & \multicolumn{2}{|c|}{4000} \\
\hline No. & 耳側 $\mathrm{db}^{\mathrm{db}}$ & 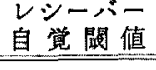 & C.O.R.A. 值 & $\begin{array}{l}\text { レジー゙ー } \\
\text { 自覚䦓集 }\end{array}$ & C.O.R.A. 值 & $\begin{array}{l}\text { レシーパー } \\
\text { 自覚閶值 }\end{array}$ & C.O.R.A. 体 \\
\hline \multirow{2}{*}{1} & 右 & $25 \mathrm{db}$ & $(-)$ & $10 \mathrm{db}$ & $60 \mathrm{dh}$ & $10 \mathrm{db}$ & $(-)$ \\
\hline & 左 & 45 & 右に片寄る & 55 & & 55 & 右に片奇る \\
\hline \multirow{2}{*}{2} & 右 & 50 & \multirow{2}{*}{$50 \mathrm{db}$} & 35 & \multirow{2}{*}{30} & 50 & \multirow{2}{*}{$50 \mathrm{db}$} \\
\hline & 左 & 5 & & 5 & & 5 & \\
\hline \multirow{2}{*}{3} & 右 & 40 & \multirow{2}{*}{40} & 40 & $(-)$ & 50 & \multirow{2}{*}{60} \\
\hline & 左 & 5 & & 5 & 左飞片答る & 5 & \\
\hline \multirow{2}{*}{4} & 右 & 30 & \multirow{2}{*}{25} & 25 & \multirow{2}{*}{35} & 20 & \multirow{2}{*}{25} \\
\hline & 左 & 5 & & 5 & & 10 & \\
\hline \multirow{2}{*}{5} & 右 & 45 & \multirow{2}{*}{60} & 50 & \multirow{2}{*}{55} & 45 & \multirow{2}{*}{35} \\
\hline & 左 & 35 & & 35 & & 30 & \\
\hline \multirow{2}{*}{6} & 右 & 5 & \multirow{2}{*}{15} & 5 & \multirow{2}{*}{5} & 15 & \multirow{2}{*}{25} \\
\hline & 左 & 15 & & 15 & & 35 & \\
\hline \multirow[b]{2}{*}{7} & 右 & 55 & $(-)$ & 55 & $(-)$ & 45 & \multirow{2}{*}{65} \\
\hline & 左 & 25 & 右 不正 確 & 25 & 右 不正 碓 & 40 & \\
\hline \multirow{2}{*}{8} & 右 & 5 & \multirow{2}{*}{20} & 5 & \multirow{2}{*}{20} & 10 & \multirow{2}{*}{80} \\
\hline & 左 & 35 & & 30 & & 70 & \\
\hline \multirow{2}{*}{9} & 右 & 30 & \multirow{2}{*}{25} & 20 & \multirow{2}{*}{25} & 40 & $(-)$ \\
\hline & 左 & 25 & & 20 & & 45 & 右に片寄る \\
\hline & 右 & 35 & & 25 & & 60 & $(-)$ \\
\hline 10 & 左 & 50 & 80 & 30 & & 70 & 左に片寄る \\
\hline
\end{tabular}

成人難聴者の自覚的 C.O.R.A. 闑值』（感音難聴）

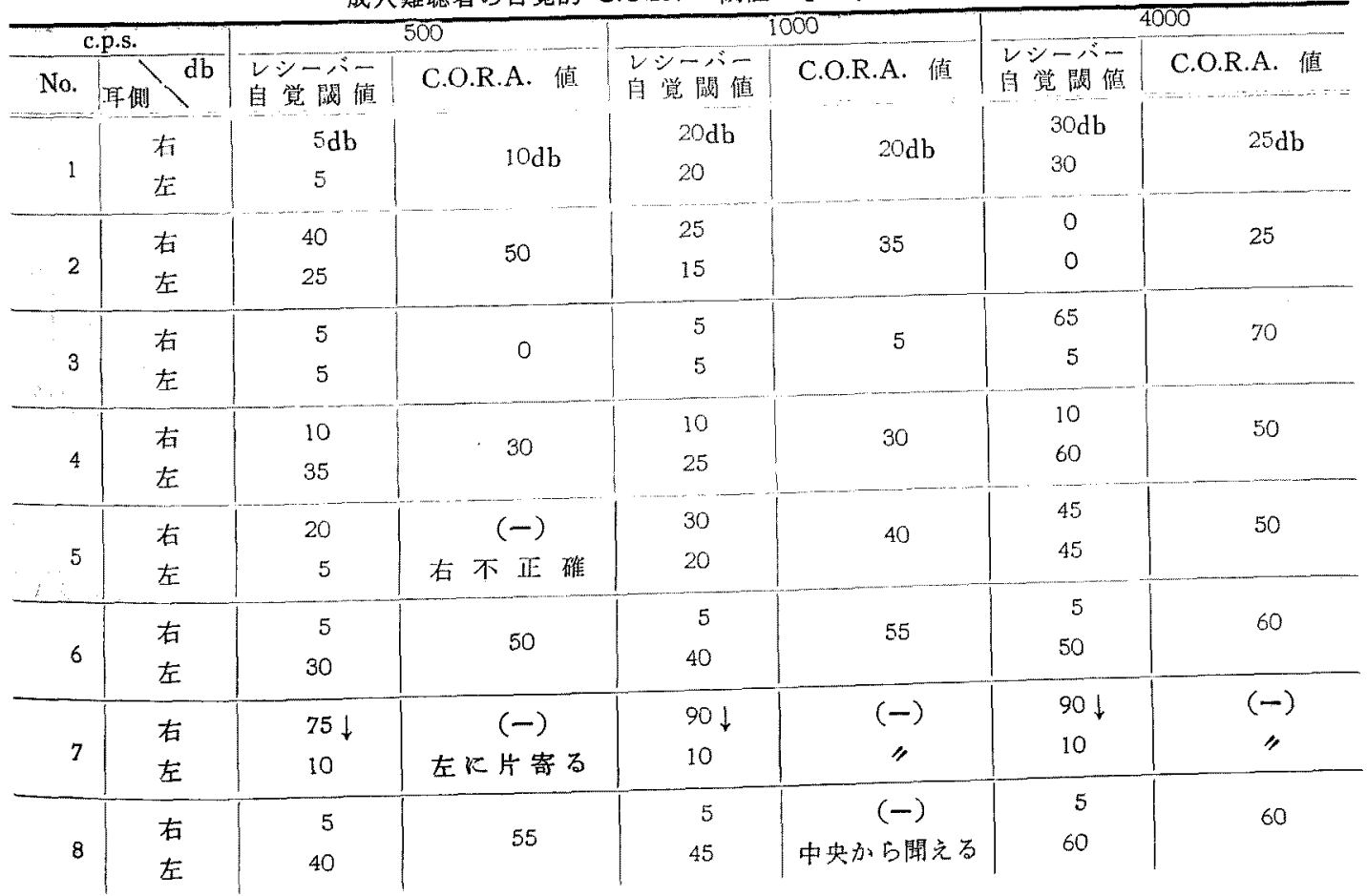


中央から聞えてくるとする症例（『の8) 等があり，個 人差が大きく，不安定である，しかし，難聴型別または 周波数別に上る特異的变化と考光られるものは全く認め られない。

E) 小 括

1）難㯖又は言語障害見では，正常児に比して適応範 囲が拨大し年長児まで及ぶ.

2) C.O.R.A. 閶值と Play audiometry 平均闘値と の差をみると，分散度が大きく $| \pm 35 \mathrm{db}|$ 以上にわたり， 一定の傾向を認めない。

3）左右聴力差のある症例では，C.O.R.A. 間值と良 悪两耳各個の Play audiometry 闒値との関係は三つの タイプに分けられ，抽出した左右聴力差 $20 \mathrm{db}$ 以上の 10 例中, C.O.R.A. 䦪値が悪聴耳閾値とほぼ一致するも のが 8 例，他は良聴耳闒值と一致または中問値を示し た.

4) C.O.R.A. 閖值と Play audiometry 良覀両聴耳 閔值との相関々係を求めると，C.O.R.A. 閔值は $1 \%$ 以 内の危険率で悪聴耳䦪值により強い相関々係を有する.

5) 成人難聴者の C.O.R.A. 閔值測定の結果多くは悪 聴耳閔値附近の值を示したが個人美が大きく，不定であ る. 難聴型，周波数別の特異的変化はみとめられない.

\section{III. 難聴児 C.O.R.A. の一工夫}

前章に述べた如く 難聴胃，特に両耳㯖力に羑のある例 に C.O.R.A. 原法にそつて施行した場合， C.O.R.A. 闘值が大多数の例で悪聴耳閾值と一致またはその附近の 值を示すことがわがのた，著者はこの原法にさらに若干

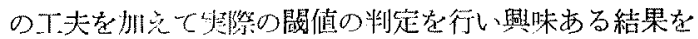

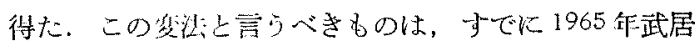
が発表している改良法と頪似する点もあるが，C.O.R.A. の精度をより高くし，かつ臨床的価値を高め得ると考古 るので，臨床例を示してその概要を報告する．

\section{A) 測定方法:}

I章に詳述した同一の䒾置を用い，はじめにC.O.R.A. 原法にそつた下降法で閥值を各周波について測定する。 次にふたたび 1000 c.p.s. にもどり，Odb より迎に上舁 法で順序，回数を不規則に左右の音源上り音の及を与 党，最初に反応のあつた（必らずしも振り向き反応でな く，音刺㦸を知覚したと確認でさるような動作，行動を 指標とする）レベルで，2〜3回左右不規則炕音を与え， 発振した音源と反応の様子を観察し，左右どちらからの 音に反応したかを確認する，このよらにして最小可聴䦥 值之その方向を決定する。つひいて各周波数についても
同様な操作をくり返す．この際，この方法の前段階のみ で検查に與味と関心を失つてしまらょうな症例では，後 段階は装置をそのまま利用し，純音のかわりにテーブレ コーダーにあらかじめ録音されてある動物の擬音に切り 換觉，同様に上犁法で最小可聴間值とその力向を決定す る. 即ち，本変法は C.O.R.A. 原法々純音又は擬音に上 る Startle response audiometry との組み合わせと云 らことができよう。

B) 湘定対象及び結果:

本変法を試双た莚例は多数あるが，必ずしも全例で 成功したと言うことはできない，本章ではそのうちで Play audiometry で測定結果の確認できたもの 8 例, Play audiometry 不能な奻小児 3 例をとり上げた（因 $8 \sim 18)$.

症例 1：3才゚，上昇法では右側に反応し，C.O.R.A. 原法による間值と $15 \sim 25 \mathrm{db}$ の差があつた. 2 日後施行 の Play audiometry では左右耳の閣值間k 20 30db の差を認めた。

图 8 症例 1

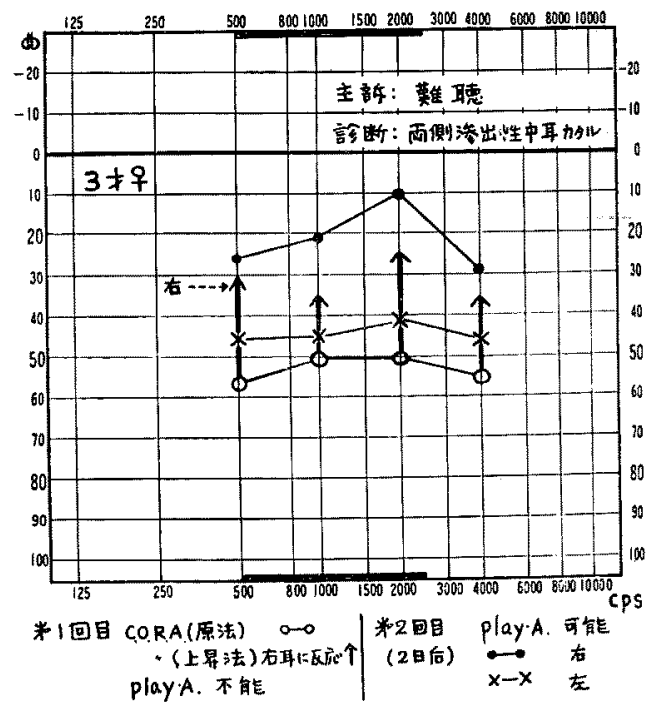

症例 2：3才方，上栎法で右側に反応し， C.O.R.A. 原法による閔値と $5 \sim 15 \mathrm{db}$ の差を認めたが，1日後の Play audiometry で $5 \sim 15 \mathrm{db}$ の閾值差が認められた。

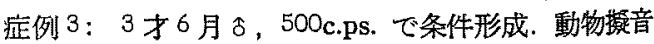
による上第法で右側に反応，C.O.R.A. 原法による䦥值 
图 9 症 例 2

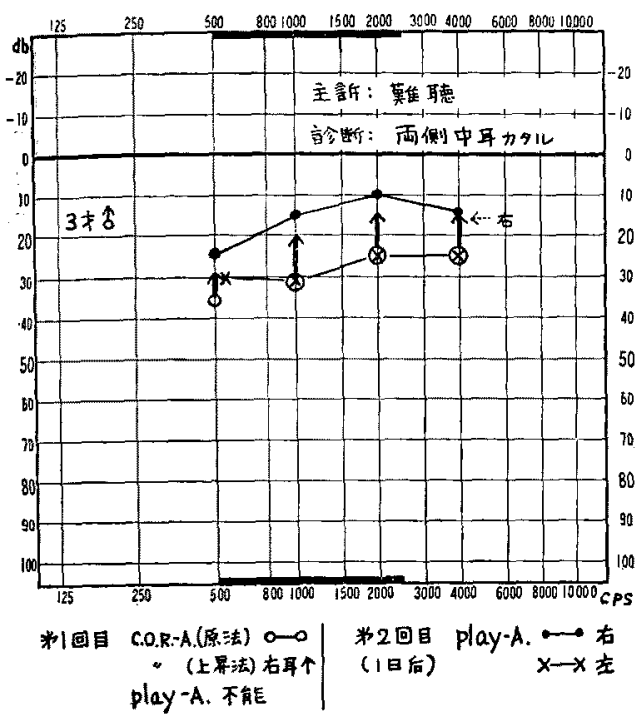

图 10 例 3

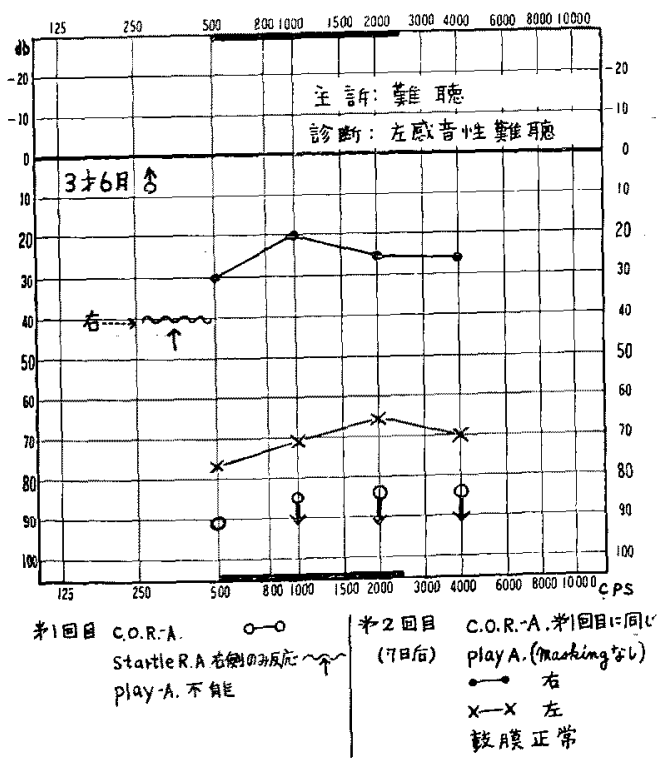

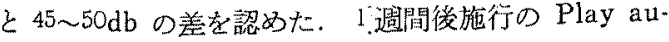
diometry では左右閶值間K 40〜 50db の差を諗め, 左 感音難㯖之診断.

症例 4: 4才o, 高音部難聴の例で, 上算法で右側に 反応，C.O.R.A. 原法による閶值之 1000 c.p.s. で $5 \mathrm{db}$ ， 4000 c.p.s. で $30 \mathrm{db}$ の差を認めた。同時施行の Play audiometry 閾值でほぼ一致の值を諰めた。
图 11 症 例 4

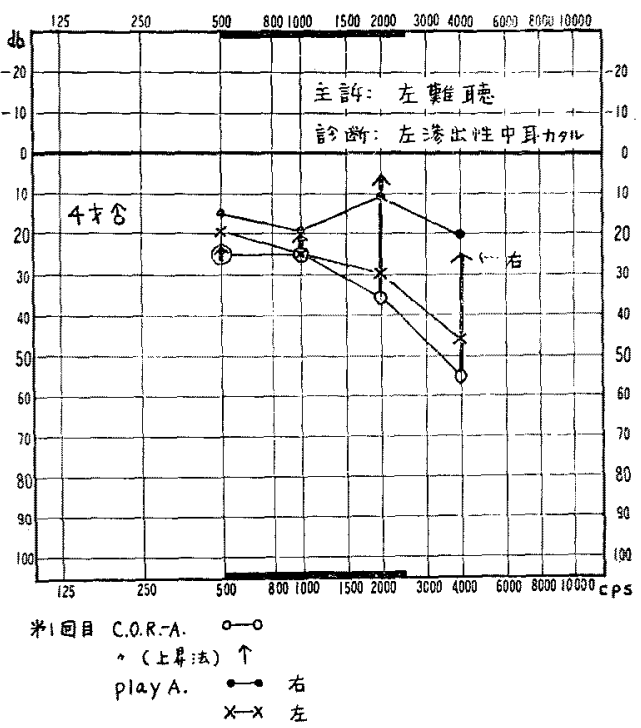

図 12 症 例 5

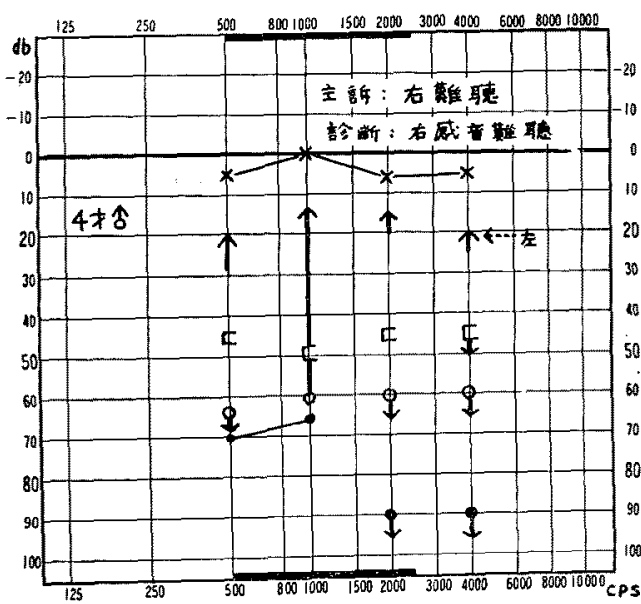

*1回自 C.O.R.A. (原法) 0 -

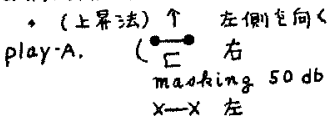

症例 5：4才可，C.O.R.A. では 1000c.p.s. で条件形 成はできたが，他の周波数では反心圭さなかつた。上 舁法で狸左側に反応し，同時に施行し得た Play audiometry で右側高度難暗上診断さ秃た。

症例 6: 4 才。，C.O.R.A.で条件形成が困難なため 不能．上昇法では正常蝺国内で左側䎲区応を示した，同 
图 13 症 例 6

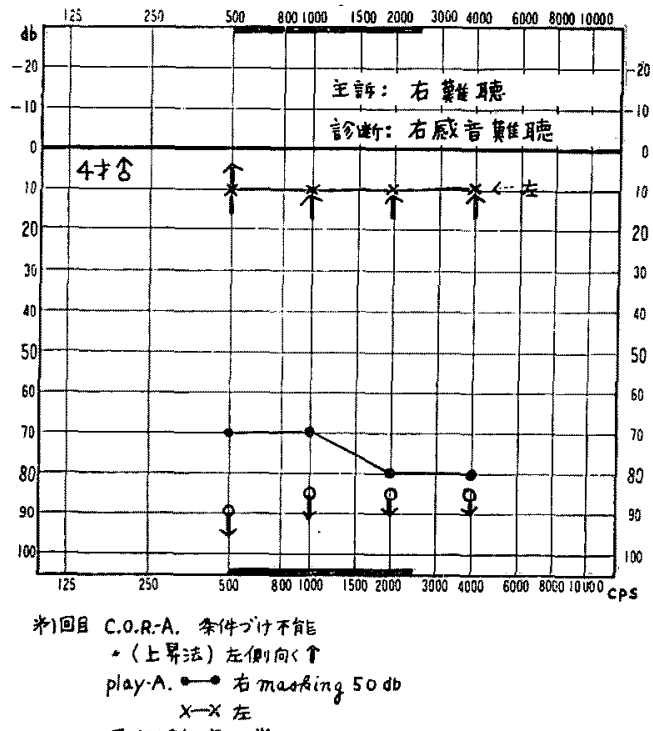

西侧鄱膜正常

图 14 症例 7

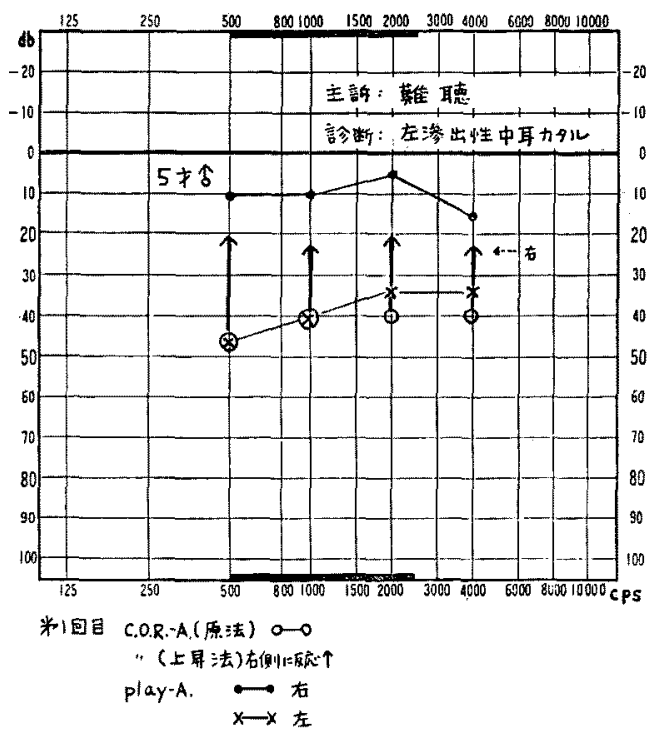

時に施行し得た Play audiometry;で右側高度難聴之猃 断を確定し得た例である。

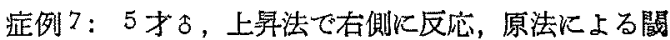
值と 20〜25db の善を認めた. 同時施行の Play audiometry でる右左耳閖值間に 20〜35db の差を示した.

症例 8：5才゙る，上昇法で左側に区広，500c.p.s.では
图 15 症 例 8

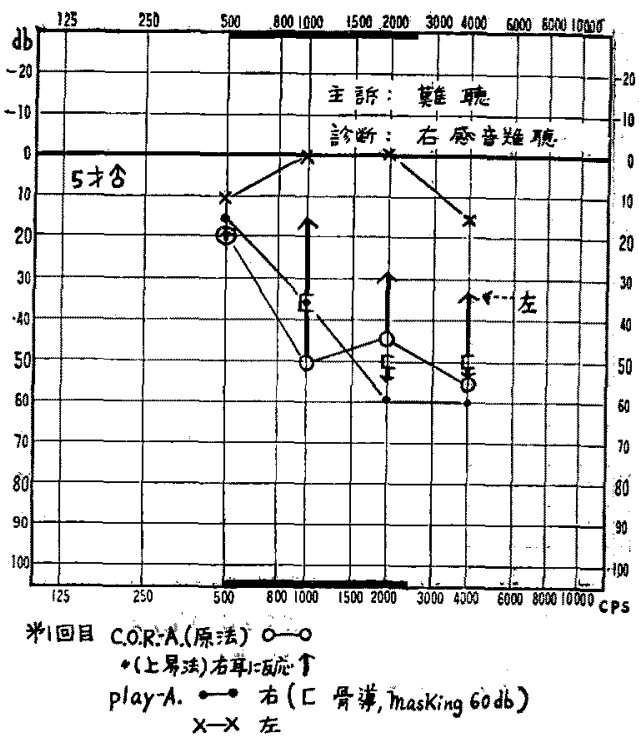

図 16 症 例 9

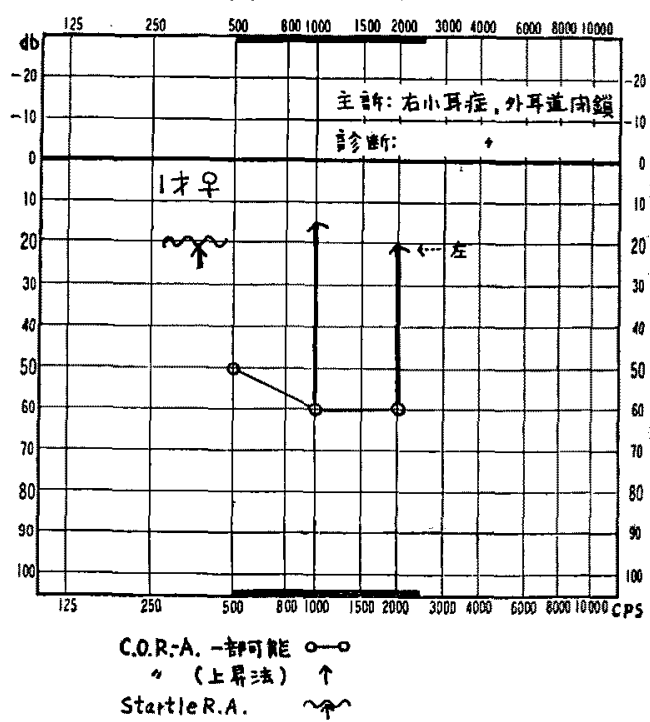

C.O.R.A. 原法閔值と上年法の閶值は一致したが，高音 部では 15〜35db の差があり，Play audiometry によ り左側正常, 右側感音難聴と診断された。

症例 9：1才早, 上昇法で左側に反応し，C.O.R.A. 原法愎一部可能.

症例 10：1才4月今，C.O.R.A. 原法で500c.p.s. の

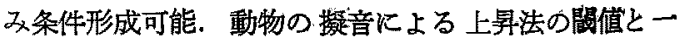


图 17 症例 10

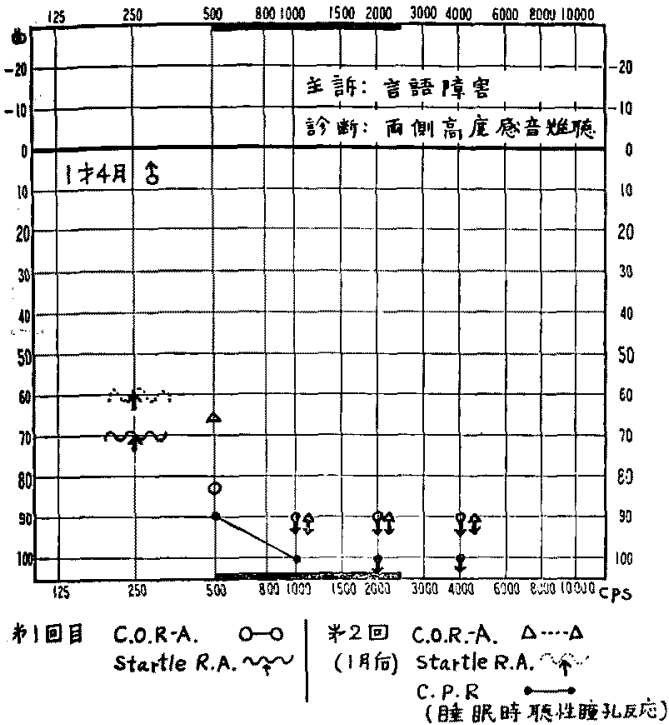

図 18 证 例 11

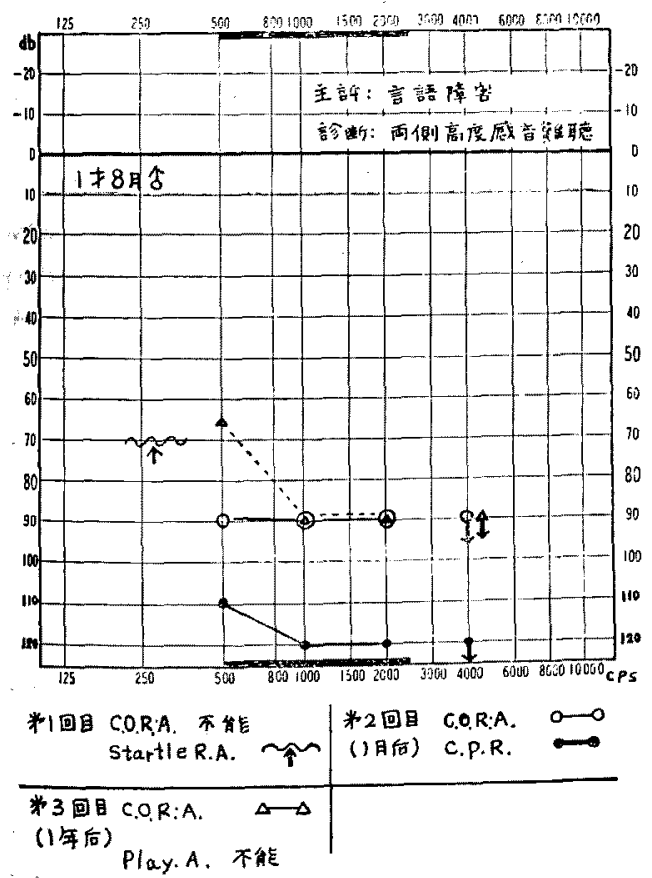

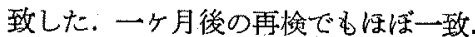

症例 11:1才8月吕.

以上症例 $9,10,110^{3}$ 例は後刻 C.O.R.A., Play audiometry 雨者が可能となつた時期に再度確認老行

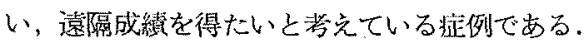

C) 小 ...括

C.O.R.A. 原法と上腎法，即ち純音又は擬音による Startle response audiometry を組名わ合わることによ

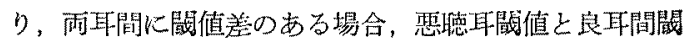
值差を求め得ることを認めた。上䒜法によつて得られ る最小可聴闖值は 良聴耳閶值と考えられる場合が多い ことを絽険した、末た本変法を使朋することにより，

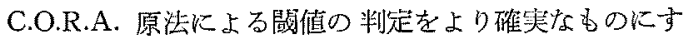
ることが可能であること壳確認した。

\section{IV. 綜括及び考按}

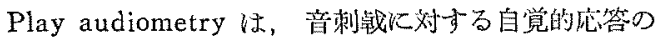

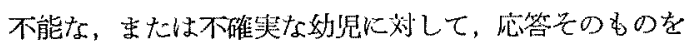

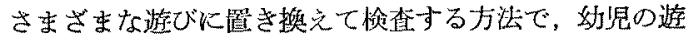
びが即，检者にとつては㯖力測定の指標となる。Play audiometry は Dix \& Hallpike ${ }^{1)} の$ Peep show test, Barr 2) の Series game 及び, Bloomer ${ }^{15)}$, Myklebust 16)等の純音と社会音や動物の鳴き声との組み合小せによ る万法の3 万洗で代表さ机，現在までの多数の ${ }^{1718) 19220}$ 報告がなされているが，本邦で惊 Peep show test を

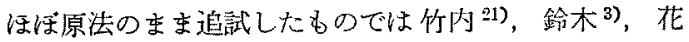
剛 22）等の報告があり，要法としては服部 23) のランブ

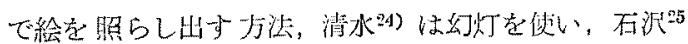

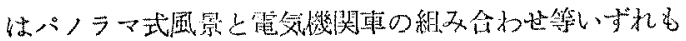
Peep show test ‘るらに子供に與味樑くするために工 夫したもので斿る。㕛，1955尔 Barr が Series game に上る詳細な研究を热表して以来，本邦でも花岡，㴖部 26)，福島 27) が斯石や綵き等を使朋した成績を発表し

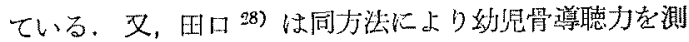
定した成績を屏告している．Play audiometryはこの

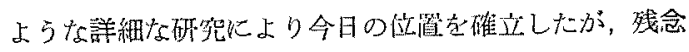
なことには Play audiomtery の適心公令下限は满 3 才

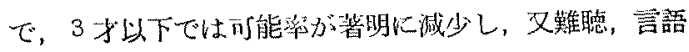
障害先や知能障需のある塲合にる年令限界が上昇する難 点がある、しかし，剆定閶值については，各面での比較 检討により信頼度の高いことが確認されている．幼层 に括ける Play audiometry 測定間值は，成人に括ける Standard audirmetry と等洒的に評洒してよいと考え

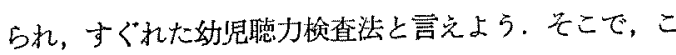


れに匹敵するる才以下の乳奶览に適心可能な臨床聴力検 查法として考案されたのが C.O.R.A. である. 本法の原 理は鈴木，荻場等が 1960 年の報告4)で詳述している如 $く$, Peep soow test $の$ Skinner 型条件反応をさらに 簡易化したものである。即ち，Peep show testでみら

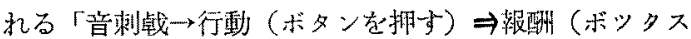
の照明がつく」の行軗を，振り向き反応と言う，より primitiveな形で把握し，3戈以下の乳奻児にも適応す るよう工夫したるのである．Ewing ${ }^{29}$ によ剠ば，音源 に正しく振り向く能力は，正常児では生後 7 ケかからみ られ，11ケ月になると頭を向けてその方问に眼を向け ることが他のどんな反応上り頻繁，から早いと述べてい ๘.

同じくEwing は1944 年楽器音や会話音を使つて乳 幼罗の反応を観察し， Startle response audiometry の 緒をひらき，その後 Myklebust ${ }^{16)}$ は2つのスピーカ

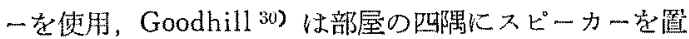
き閔值の測定な行つた，木邦では，花岡 ${ }^{31)}$ が動物の擬 音を使用して行つたもの先はじ佐藏 ${ }^{32)}$ ，田村33)，前 沢 94) 等が社会音，純音を用いてこの方法老試みている。 Statle response audiometry の閶値の測定には乳幼胃 の音に対する種々な反応を指慓上しているが，高木 ${ }^{35}$

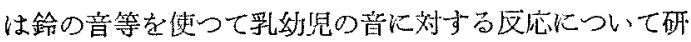

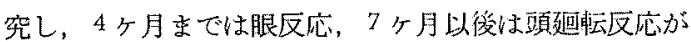
大部分を占めたと Ewing とほぼ同じ襩察をしている。 C.O.R.A. はこの上万な乳炒览の音に対专る非特買的反 沁の中から，振り向くと言う特定の反応を測定の指摽と して選び，Skinner 型条件反応にとり入れたことに特 長がある。しかも，生理学上から C.O.R.A.の上うな条

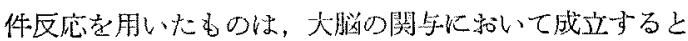
容らことが考总られるので，無条件汉射を利用した測定 法に比して聴覚とのものにより近い电のを测定している と謂える。しかし，このことからも本法が新生見や，こ

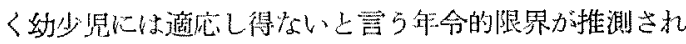
る.

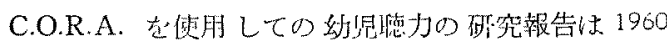

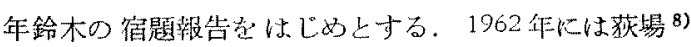
は，1 才未满児にむ適応する改良法を案出し，1才以下

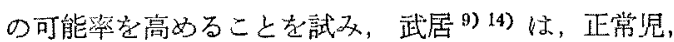

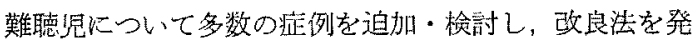
表している。本邦外ては，1961年 Trenque ${ }^{11) ， 1962 ~}$ 年 Schröder 1')，1964 年 J. Floux-Guyot 12) 等が槴試

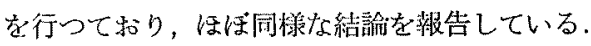

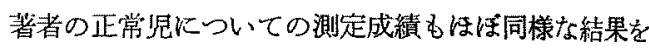
得た。

可能率についてみると，武居は原法により1〜1：5才 $79 \%, 1: 6 \sim 1: 11$ 才 $87 \% ， 2 \sim 2: 5$ 才 $82 \% ， 2: 6 \sim 2$ : 11 才 $92 \% ， 3 \sim 4$ 才 $64 \%$ ，さらに1才未满胃用改良法で 0.8 才以上で $80 \%$ を越す良い成績を埌告している，著 者の例では1才末满 $29 \%$ ，1 2 才来满 $83 \% ， 2 \sim 3$ 才末

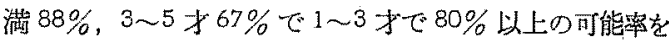
示し，本洗の刘象としてはこの年命群がもつとも道当で あると謂えよ5．及，他の検查法の可能䜌之の比較でも この事実が証明され，年長児で C.O.R.A.の可能率が低 下寸る反面，Play audiometry の可能の割合が增加す ることは，Play audiometry の限界と C.O.R.A. の適 応年令との関係を示して興味深い。

可聴閾值については，Play audiometry に上る满 3 才以上の対象(゙は Westlake ${ }^{36)}$ ), 福島 ${ }^{27)}$ ，石沢 ${ }^{25)}$ ，花 阔 ${ }^{22)}$ 等の報告があり，年令の增加と共に成人閶值倿 近すると謂う。また佐藤 ${ }^{32)}$ は，Startle response audiometry でも年令の進むとつれて潮次成人閶值に近つく 之報告し，荻場，武居は，C.O.R.A. に上る満 3 才゙以下 の正常乳幼児の场合でも同じ佰向を認める之謂い，著者 の測定成續でも同様な所見を推認した，即ち，正常乳奻 児の C.O.R.A. 綜合平均閶値は，1 才未满 $24.7 \mathrm{db}, 1 \sim 2$

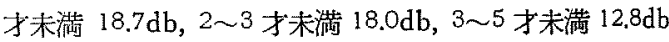
で，周波数別にみると高音部に渐傾している，こ扎忹武 居の成績 ${ }^{9)}$ とほ添同じ值を示した。

Play audiometry 閔値との比較では，雨者の差が士 $5 \mathrm{db}$ 以内に全体の $80 \%$ 以上が含まれ，再检査可能例以 つての闎值の比較でも，变動が $5 \mathrm{db}$ 以内の例が 89 $\%$ と湘定值の恒常性が䛑められ，C.O.R.A. Kよる湘定 閾值の信頼度の高いことを確認した。

ここで闑題となることは，乳幼児の測定値は成人の自 覚閣値と同一視できるか否かといら点である。測定閶值 が年命の增加と其炕成人闒值に接近する成績をどの上ら

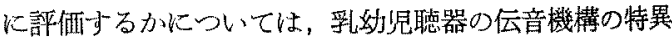

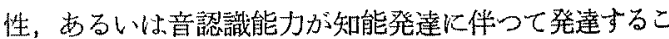
とに起因する，等の説明がなされているが，目下のとこ

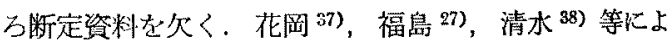
れば，知能と聴力の相関々倸はないと謂ら。

以上，正常児の C.O.R.A. 測定成績は，幼児の真の聴 力を測定したものとは謂い、難いが，すくなくとも㯖力の 生理的発達過程を呈示していると見做してよいである 5. 
このよらに正常児にあつては可能率が高く，信頼运の

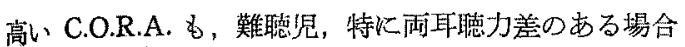
には，測定が困難であったり，間値の信頼性に䈝㢳が生 じたりする。この問題は武居がすでに指据して招る如 く，本法が自由音場で，二つの異なる方向からの音を聞 くことにより両耳綜合聴力を得るといらことに起因与る と考党られる。自由音場での方向音觉については大内

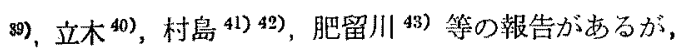
それによれば，難德者は正常者に比して方向音覚が琹 く，雨耳の聴力差の大きい程音源方向に対する䛊差も大 きくなると謂ねれている，聴力障害別では，肥留川41), Nordland 44) 45) は，伝音障害の埸合むしろ方向音覚が 悪い，と述べて扔るが，この点については複雑な要素が 関係しているょうである.武居 ${ }^{14)}$ は C.O.R.A. の装置 で成人について，方向音覚，音源の方问に上る聴力の壆

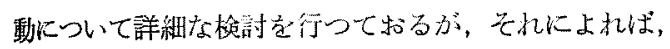

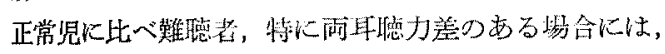

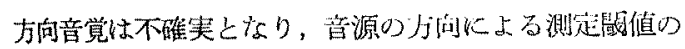
変動も著しいと述べている．以上はいづれも成人につい

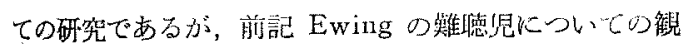

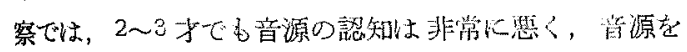
示した場合や，頻回の刺战のあとでよらやく認紌する， とあり，難㯖乳幼悲の力问音覚が成人以上に想いしとを 推測させる。

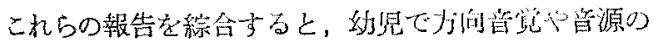
方向による闌值の変動を調べることは活とんど何能で

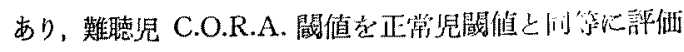

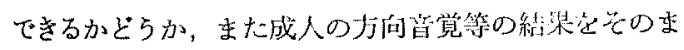

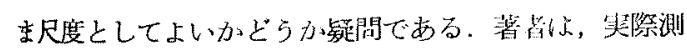
定された C.O.R.A. 闌䛧を多触に娭討广ることによ

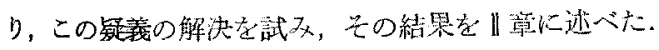

測定成績加判ること结, C.O.R.A. 琙値々 Play audiometry 可均䤋值の差を見ると，士55db 以上にわ たるハシラッキを示し，再都の間に相阙么係がないかに

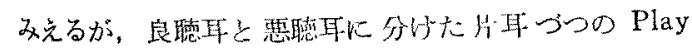

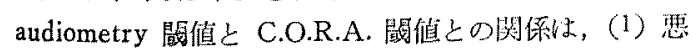

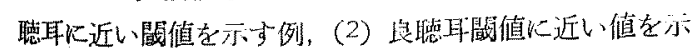

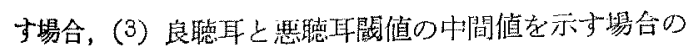

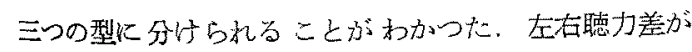
$20 \mathrm{db}$ 以上の 10 例中，(1) K属する例が 8 例と多数を占 めている。ささらに対象全体を無作為的に分けた良㯖耳 群，悪缌耳.群の C.O.R.A. 關値己 Play audiometry 閩値との相関々係を求め，ての相関比をみると，1000 c.p.s. $6.32,2000$ c.p.s. 3.75 , 4000 c.p.s. 3.28 , 500 c.p.s.

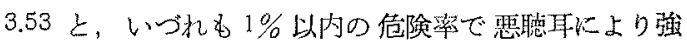

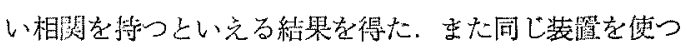
て，自覚法に上る成人難聴者の C.O.R.A. 闇值を測定し た結果多数の症例て偲聴耳閾值と一致することがわから

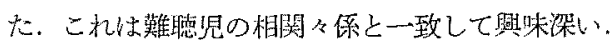

一般に幼胃では，自由音場で两耳綜合間值を測定した

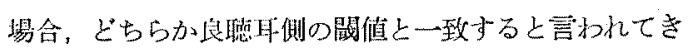
た. 若岡 29) は peep show test で, 石沢 25) は peep show test 变法で左右㺊力差の妨る10症例について測 定した結果， $5 \mathrm{db}$ 以内の美で良聴耳閭傎と一致したと 述べている.これ诰者の C.O.R.A. 間值について得た 結祭と矛盾寸る。この矛盾は peep show test が方向音 賞の認知を前提としないことに此して，C.O.R.A. が二

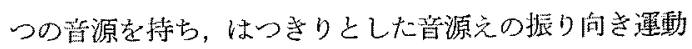

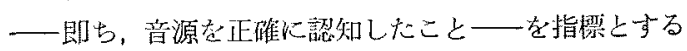

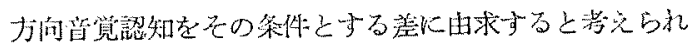
る.

しかし、ここで注意すべさ点は，すべての应例が上述 の如き反応走示のではなく，阔耳間值差がないにるか

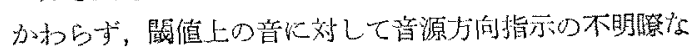
例，雨耳德力差がある例ですべて良聴耳側から聞えると 寸る例，闖值上の晢がすべて中央から聞えるとする例等

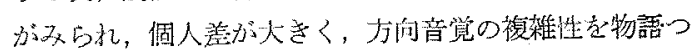
ている，又，成人の塌合は䪽位を正中に固定したまま测

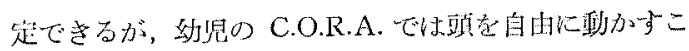

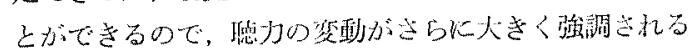
ことが考えられる。

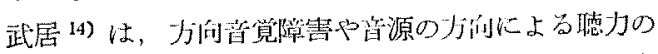

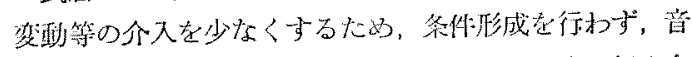

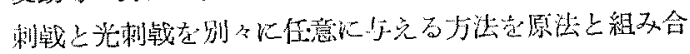

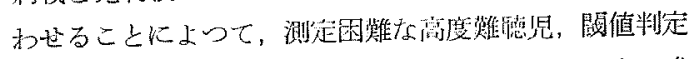

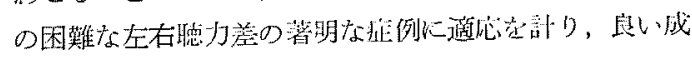
縝を得ている。

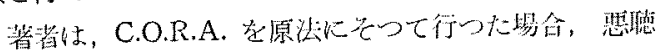

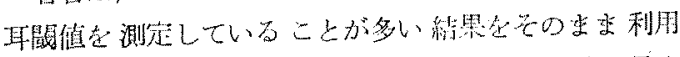

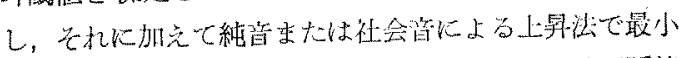

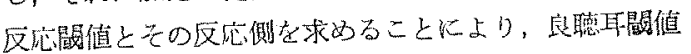

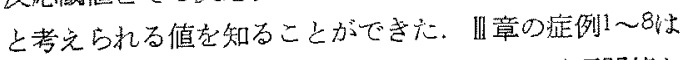

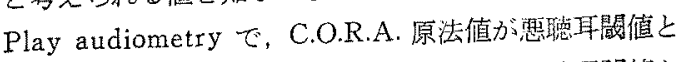

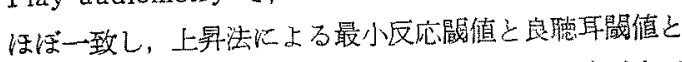

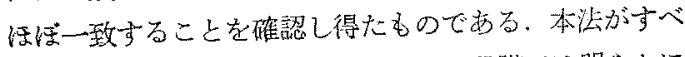

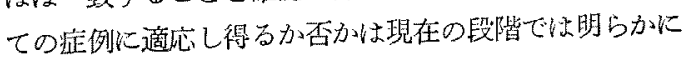


なし得ないが，C.O.R.A.のみで左右の聴力を同時に測 定し得る可能性を示燖し興味樑い。

奻児聴力㭘查の矿究者が挙つて述べているように，現

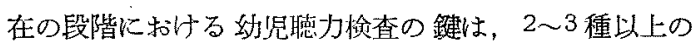
検査を合わせ行うこと，不確实な場合は，再倹查を合わ 世行らことにあると謂つて扔るが，藷者もその必要性を 痛感した，C.O.R.A. を最初に行らことにより，检查の 障害となる幼览の恐怖心や不安感を取り除き，恰査飞親 し及を持たせ，次の段階で Play audiometry 飞容易に 導くことができた症例の多かつたことは，本法の日常臨 林険査法としての長所の一つであると考えられた。

以上，本論文では C.O.R.A. 闇值を Play audiometry 可能であつた症例を中心取り上げたが，C.O.R.A. のみ可能であつた症例については，今後更に経過を钼察 することにより，本法の信頼度その他についての遠嵒成 績の検討に資する予定である。

\section{$\mathbf{V}$. 結語}

C.O.R.A. を原法に準した測定方法で，正常児 186 名， 難聴，㝘語障害照 222 名に施行し，その測定成績を推計 学的に処理し，検討を加え，次の結果党得た。

（1）正常児では，可能率は1 2 抹満 $83 \% ， 2 \sim 3$ 才未満で $88 \%$ を示し，本法の至適全令は1〜3才であ る. 難聴、言語蹱㕩览では適応年令の摭大を認め，11 月〜9才で平均 $82 \%$ の可能㻭を示した。

（2）正常児の C.O.R.A. 年令別汗约閾値は，1才未

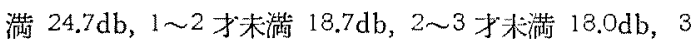

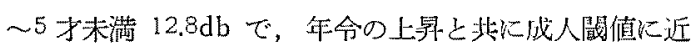

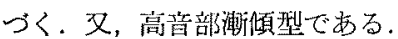

(3) 正常児 C.O.R.A. 閾値と片耳づつの Play audio-

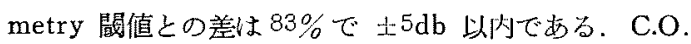
R.A. 再検查可能例ては，雨榆查値の差

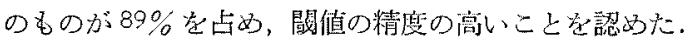

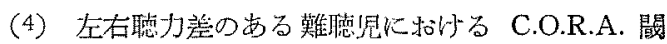
値之良瑟阿耳各個の Play audiometry 闎値との関倸は 三つのタイプK分けられる，抽出した Play audiometry 左右闒値差 $20 \mathrm{db}$ 以上の 10 例で， C.O.R.A. 閶 值が悪聴耳間值とほぼ一致するものが 8 例，他忹良聴耳 閔値と一致または雨者の中間値を示した。

（5）難聴児 222 名中, Play audiometry をむむ子せ て施行し得たるのは82 例で，その Play audiometry 閥值を悪聴耳と良聴耳とに分け，C.O.R.A. 闒值との相 関々係をみると，相関俰数性 1000 c.p.s. 良聪耳 0.727 , 覀聴耳 $0.982,2000$ c.p.s. 良聴耳 0.671 , 恐聴耳 0.931 ,
4000 c.p.s. 良聴耳 0.695 ，墨恥耳 $0.923 ， 500$ c.ps. 良聴 耳. 0.50 ，悪聴耳 0.877 となり，相関比を求めると，各 周波数之も危険率 $1 \%$ 以内で，C.O.R.A. 閔值悢良聴耳 よりも悪聴耳䦪值により相関が強いと謂光る. 即ち, C.O.R.A. による測定值は多くは，恶㯖耳間值を䁚定し ていると謂える。

（6）C.O.R.A. 原法に純音委たは社会音による上昇法 を加えて施行する C.O.R.A. 変法と云うべきるのを工夫 した，本变法は閶値の判定を確笑にし，左右㯖力差のあ る場合には，良悪雨耳聴力を同時に測定する可能性すあ ることが分つた。

\section{文献}

1) Dix, M.R. and Hallpike, C.S.: The peep show. A new technique for pure tone audiometry in young children. Brit. M.J., 2; 719, 1948.

Barr, B.: Pure tone audiometry for pre-school children. Acta Otolaryng. Suppl. 121: $1955 . \quad 3)$

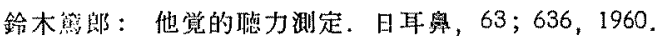
4) 踰木第郎：他覚的聴力測定法. 日耳鼻, 第61回総会 宿題報告別刷，1960．5）荻場芳雄：3才未满の幼

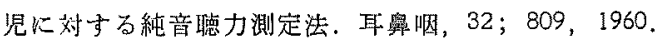
6）荻場芳雄：条件涂索反射聴力测定法（C.O.R. audiometry）の検討. 日耳睤，64；855，1961。 7) Su$z u k i, T$. and Ogiba, Y.: Conditioned orientation reflex audiometry. Arch. Otol., 74; 194, 1961. 8)

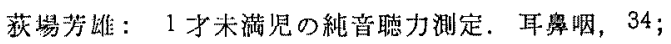

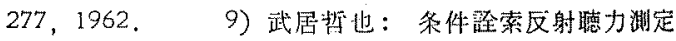

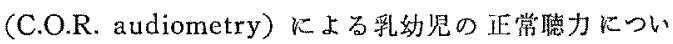

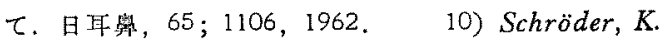
et Relke, W.: Probleme der Kinderaudiometriedargestellt an der Methode des bedingten Orientierungsreflex. Z. Laryng. Rhin., 41; 682, 1962 . 11) Trenque, P. et Lafon, J.C.: Les troubles de l'audition chez lenfant et leur mesure. (13) より引用. 12) J. Floux-Guyot.: Le Reflexe Dórientation Conditionne (R.O.C.). J.F.O.R.L., 13; 43, 1964, 13) 大下富美代：乳奻児聴力障害の研究. 日耳鼻，68;1134， 1965. 14) 武居哲也：条件詮索反射㯖力測定 (C.O. R. audiometry）の改良に関する研究。日耳畨，66; 1366, 1963. 15) Bloomer, H.: A simple methode for testing the hearing of small children. J. Speech. Dis., 7; 311, 1942. 16) Myklebust, H.R.: Auditory disorders in children. Acta. Oto-Laryng. 
SuppI. No. 121; $1955 . \quad$ 17) Denmark, F.G.W.: A development of the pee-show audiometer. J. Laryng., 64; 357, 1950. 18) Guilford, F.R. and Hang, C.O.: Diagnosis of deafness in the very young child. Arch. Otolaryng., 101, 1952. 19) Wishart, D.E.S.: Problem of hearing defect in children. Ann. Otol., 61; 762, $1952 . \quad 20)$ Green, D.S.: A simple inexpensive modification of the peep show. J.S.H. Dis., 23; 118, 1958. 21) 竹内和夫: 小

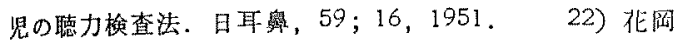
集: Play audiometryによる奻罗の正常聴力につい て、日耳鼻, 60；879，1957。23) 服部濫：聴覚の 臨床的研究. 耳鼻臨，47；663，1954。24）清本弘: 小児聴力検査の一方法.耳與咽，29:393，1957。25)

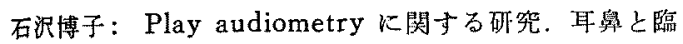

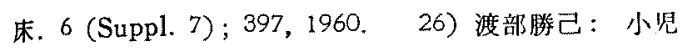
班力换査法の研究. 日耳鬼，62；1583，1959。27)

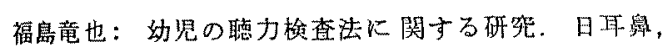
63 ; 1835，1960. 28) 田口韾一郎: Play audiometry による纤睍の正常骨導㯖力について。耳鼠咽，34；185， 1962. 29) Ewing, I.R. and Eving, A.W.G.: The ascertainment of deafness in infancy and early childhood. J. Laryng., 59; 309, 1944 . 30) Goodhill, V.: Directional free field startle reflex audiometry. Arch. Otolaryng., 55; 597, 1952.31$)$ 花岡葉: 乳 幼児㯖力娭查法の一工夫. 日耳奥，62；940，1959. 32) 佐藤育蔵：第愕反応聴力测定法心関する研究。日 耳奥，65；755，1962，33）田村実: 幼児聴力検查法 化関与る研究。日耳鼻，65；1348，1962。34) 前沢

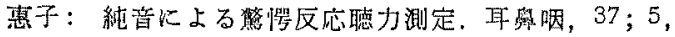
1965. 35) 高木二郎：乳児の音飞対する反応につ いて. 耳䕗咽, 36；649，1964. 36) Westlake, H.: Hearing aquity in young childrin. J. Speech and Hear. Dis., 7；714，1942,37) 花岡葉：幼坚正常聴

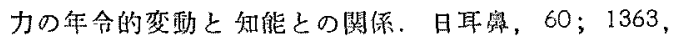

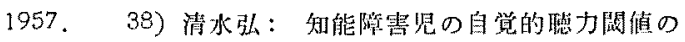
售頼性，耳與咽，37；32，1965。39）大内仁，他：

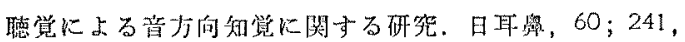

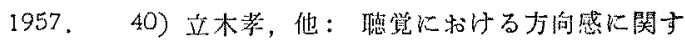

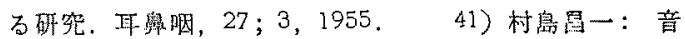
源の力向による聴力の変動に就いて。日耳索，62；704， 1959。42) 村島曷一：自由音場検查による聴力の橭 人差について。昼鼻，60；1235，1957。43）肥留 川恒一郎: 方向音覚の研究, 耳鼻臨，52; 62, 1959. 44) Nordland, B.: Directional Audiometry. Acta. Otolaryng., 54 ; 75, $1962 . \quad$ 45) Nordland, B.: Physical factors in angular localization. Acta. Otolaryng., 54; 75, 1962.44) 林鄗品：条件反射. 悲诐全畫, 1963 .

稳を終るに当り，御指臬御校閲をいただいた 䍐師猪初男教嗳に梁甚なる謝意を表します。又 稆始親切に御指導下さつた佐藤隆三䛾師，御協 力頂いた教室の諸先生方，特に聴力班の諸先生 に感謝いたします。な找諭の要旨は，第9回 日本オージオロジー学会に和いて発表した。

（原椡到着=昭和 41.1 .29 日） 